Metall. \& Mater. Trans. A., v. 32A, 2001, p. 2175

\title{
Determination of the CoTi Congruent Melting Point and Thermodynamic Re-assessment of the Co-Ti System
}

\author{
A.V. DAVYDOV, U.R. KATTNER, D. JOSELL, J.E. BLENDELL, \\ R.M. WATERSTRAT, A.J. SHAPIRO, and W.J. BOETTINGER
}

New experimental results and a thermodynamic re-evaluation of the Co-Ti system are presented. Using differential thermal analysis and a visual observation of melting technique, the $\approx 220 \mathrm{~K}$ inconsistency in melting temperature in the literature for the B2 (CoTi) phase is resolved. The congruent melting point is determined to be $1776 \mathrm{~K} \pm 5 \mathrm{~K}$. The revised $\mathrm{B} 2$ melting temperature along with other critically reviewed thermochemical and phase equilibria data from the literature are used to re-assess the thermodynamic description of the Co-Ti system. As a result, a self-consistent set of optimized Gibbs energy expressions for all Co-Ti phases is obtained.

\section{INTRODUCTION}

Cobalt and titanium are important components of many industrial alloys. Information on phase equilibria and thermochemistry in the Co-Ti system is essential for development of thermodynamic databases of Co- and Ni-based superalloys. Such databases ${ }^{[1]}$ are important for process modeling; e.g., solidification, homogenization, transient liquid phase bonding, and $\gamma / \gamma^{\prime}$ precipitation. In addition to superalloy applications, a new class of $\mathrm{Co} / \mathrm{Ti}$ multilayer magnetic devices and neutron polarizers is emerging, ${ }^{[2,3]}$ and $\mathrm{Co} / \mathrm{Ti}$ metallization on Si-chips is being developed for electronic devices. ${ }^{[4]}$ These latter applications make knowledge of the Co-Ti system an important tool for predicting intermetallic phase formation and stability during 
industrial processing. Therefore, an accurate experimental and thermodynamic re-evaluation of the Co-Ti system is necessary.

The phase diagram evaluated by Murray, ${ }^{[5]}$ with all experimental data, is shown in Fig. 1 . The diagram contains the following phases: the disordered solutions: liquid, A3 (Co- and Ti-rich hcp), A1 (Co-rich fcc), and A2 (Ti-rich bcc) terminal solid solutions; plus five intermetallics: $\mathrm{L}_{2}$ $\left(\mathrm{Co}_{3} \mathrm{Ti}\right), \mathrm{C} 36\left(\mathrm{Co}_{2+\mathrm{x}} \mathrm{Ti}_{1-\mathrm{x}}\right)$ and $\mathrm{C} 15\left(\mathrm{Co}_{2} \mathrm{Ti}\right)$ Laves phases, B2 (CoTi), and $\mathrm{NiTi}_{2}$-type compound $\left(\mathrm{CoTi}_{2}\right)$. The B2 is the only intermediate phase forming congruently from the liquid. Its maximum melting temperature, is uncertain with reported $T_{m}$ values varying between $1593 \mathrm{~K}$ and $1811 \mathrm{~K}^{[6-11]}$

This paper reports an experimental determination of the B2 melting point and a new thermodynamic assessment of the Co-Ti system, utilizing standard CALPHAD (CALculation of PHAse Diagrams) procedures and packages. ${ }^{[12,13]}$

\section{THE B2 MELTING POINT EXPERIMENTS}

\section{A. Literature overview}

Among the most important issues in the system is the inconsistency in the melting temperature data for the $\mathrm{B} 2$ phase. The following maximum melting temperatures are reported in the literature (from the lowest to the highest): $1593 \mathrm{~K},{ }^{[6]} 1623 \mathrm{~K},{ }^{[7]} 1722 \mathrm{~K},{ }^{[8]} 1773 \mathrm{~K},{ }^{[9]} 1799$ $\mathrm{K},{ }^{[10]}$ and $1811 \mathrm{~K}^{[11]}$ (see also Fig. 1 ). The $\approx 220 \mathrm{~K}$ range of the experimental $\mathrm{T}_{\mathrm{m}}$ values might be associated with two factors. The "upper limit" data potentially overestimating the B2 melting temperature might be linked to contamination of samples with oxygen (or other interstitial elements) which is known to stabilize cobalt-titanium intermetallic phases. ${ }^{[14]}$ Indeed, Pet'kov and Kireev ${ }^{[11]}$ reported a new high melting Ti-rich phase close to the B2 composition that was never confirmed to exist in other studies. Similarly, other high temperature $\mathrm{T}_{\mathrm{m}}$ data were 
obtained using low purity titanium with Ti mass fraction of 95 pct. $^{[8]}$ The "lower limit" $\mathrm{T}_{\mathrm{m}}$ data $^{[6,7]}$ might be linked to inhomogeneity of the B2 alloys: the first appearance of liquid in possibly "off-congruent-melting-point" compositions might have mistakenly been assigned to congruent melting. Butler et al. ${ }^{[9]}$ observed that in their material the maximum B2 melting point did not actually correspond to that for equiatomic Co:Ti composition, being slightly on the Corich side.

Thermodynamic assessments of the Co-Ti system reported in the literature, ${ }^{[5,15-19]}$ are based on different choices of the B2 melting point (Table I). The uncertainty of the actual $\mathrm{T}_{\mathrm{m}}$ value makes it difficult to adopt any particular assessment for modeling and alloy process development. To eliminate this uncertainty, we performed melting experiments in the vicinity of the B2 stoichiometric composition by two independent methods: differential thermal analysis (DTA) and visual observation of melting (VOM) technique.

\section{B. Experimental Procedures}

Three $\approx 8 \mathrm{~g}$ alloy samples were prepared by e-beam melting of approximately equiatomic amounts of high purity Co (99.95 pct) and Ti (99.995 pct) on a water-cooled $\mathrm{Cu}$ hearth in vacuum $\left(10^{-5} \mathrm{~Pa}\right)$. The samples were homogenized at $1473 \mathrm{~K}$ for $140 \mathrm{~h}$ in ultra-high-purity (UHP) argon, which was additionally purified by flowing through a Ti-gettering furnace. To further protect the alloys from oxidation during the heat treatment, samples were stacked together and wrapped in a titanium foil. Prior to the annealing, the furnace was repeatedly evacuated and flushed with Ar.

The annealed samples were ground into $10 \mathrm{~mm}$ x $10 \mathrm{~mm}$ x $4 \mathrm{~mm}$ bars, with each face metallographically polished and examined. Optical microscopy (OM), X-ray diffraction (XRD) and scanning electron microscopy/energy-dispersive X-ray spectroscopy (SEM/EDS) were used to verify the homogeneity and to determine the actual Co:Ti composition of each sample. The 
EDS measurements were performed using elemental standards on unetched metallographically polished samples. Accuracy of EDS analysis was established to be within 0.3 at pct ${ }^{*} \mathrm{Ti}$ by obtaining titanium content between 66.6 and 66.9 at pct $\mathrm{Ti}$ for the $\mathrm{CoTi}_{2}(66.7$ at pct $\mathrm{Ti})$ phase. Chemical analysis for oxygen, nitrogen, and carbon of the annealed samples was measured commercially according to ASTM Test Methods E1447, E1019-94, and E1019-94, respectively.

To determine the melting behavior of the CoTi alloys, DTA and VOM techniques were employed. DTA was carried out using alumina crucibles and W-WRe thermocouples. DTA runs were performed in pure $\mathrm{Ar}$ and in 95 vol pct $\mathrm{Ar}-5$ vol pct $\mathrm{H}_{2}$. There was no difference noted. The heating and cooling rates were $+0.08 \mathrm{~K} / \mathrm{s}$ and $-0.33 \mathrm{~K} / \mathrm{s}$, respectively. Onset and peak temperatures were noted for the melting and solidification processes.

For the VOM experiments, 0.3 to $0.5 \mathrm{~g}$ samples were cut from the CoTi bars and suspended on a tungsten wire inside of a high vacuum furnace. Alloy melting was observed through the furnace window with a $10 \mathrm{X}$ telescope during heating in 2 to $3 \mathrm{~K}$ increments with a 180 to $300 \mathrm{~s}$ holding time to allow for temperature equilibration. Two temperatures were noted during the VOM experiments: the temperature for the appearance of liquid at the sample edges and the temperature for sample collapse to a liquid-like sphere on the supporting tungsten wire. Selected DTA and VOM samples were characterized by metallographic, XRD and SEM methods.

Nickel metal of 99.995 pct purity $\left(\mathrm{T}_{\mathrm{m}}=1728 \mathrm{~K}\right)$ was used as a standard for temperature calibration of both DTA and VOM systems. Accuracy of both methods was estimated to be \pm 5 K (total uncertainty).

C. Experimental Results

1. Characterization of samples prior to thermal analysis

\footnotetext{
${ }^{*}$ Hereafter the abbreviation 'at pct' is used to express atomic fraction of element (in \%)
} 
After e-beam melting and thermal annealing of alloys and before proceeding with the melting point experiments, the Co-Ti alloys were analyzed for homogeneity and composition. According to the results of OM, XRD, and SEM, all three samples (hereafter referred to as I, II, and III) appeared to be single phase, homogeneous alloys with average grain diameters of 1 to $2 \mathrm{~mm}$. An XRD analysis confirmed that the alloys have the B2 structure with lattice parameters close to those from the literature (e.g., a $=0.2992 \mathrm{~nm} \pm 0.0003 \mathrm{~nm}$ for alloy II compared to the JCPDS data $^{[20]}$ with $\left.\mathrm{a}=0.2986 \mathrm{~nm}\right)$. SEM/EDS composition measurements were taken in different locations of the metallographic section at different positions in several grains. The averaged results were as follows: sample I, 48.1 at pct Ti $\left(\sigma_{n-1}=0.6\right.$ for $\left.n=11\right)$; sample II, 49.4 at pct Ti $\left(\sigma_{n-1}=0.6, n=6\right)$; and sample III, 50.4 at pct $\operatorname{Ti}\left(\sigma_{n-1}=0.4, n=6\right)$, where $\sigma_{n-1}$ is the standard deviation for the $n$ measurements. Commercial chemical analysis confirmed that the contamination of the ingots with $\mathrm{O}, \mathrm{N}$ and $\mathrm{C}$ was minimal: $0.07,0.01$, and $<0.01$ at pct, respectively, and therefore, had an insignificant effect on the B2 melting behavior.

\section{Thermal Analysis}

The DTA curves for samples I-III are shown in Figure 2. All curves are for the first melting of the homogenized samples so that solidification segregation was not present. Thus the curves show irregularities due to the collapsing sample in the DTA cup. On heating, all three curves were free of thermal arrests except for those associated with solidus/liquidus effects. This fact confirms that within the limits of the DTA sensitivity, the compositions of all three samples lie inside of the homogeneity range of the $\mathrm{B} 2$ phase.

Table II summarizes the onset and peak temperatures associated with the alloy melting and solidification as extracted from the DTA scans. It is also noted that during melting, heating was terminated at $\approx 1785 \mathrm{~K}$, before full restoration of the baseline due to temperature limitations of 
the DTA. Since all the peaks occur at temperatures lower than $1785 \mathrm{~K}$, they are not artifacts of power shut down.

The onset temperature on heating and the peak temperature on cooling should provide upper and lower bounds respectively for the solidus temperature for each alloy. Similarly, the onset temperature during cooling and the peak temperature on heating should provide lower and upper bounds for the liquidus temperature, respectively. These ranges are listed in Table II, in the two columns entitled "Summary, $\mathrm{T}_{\mathrm{L}}$ and $\mathrm{T}_{\mathrm{S}}$ ". It is noted that the temperature difference between onset and peak of the DTA runs during melting was generally double the value for pure Ni. Thus the peak temperatures on melting are a better estimate of the liquidus that the onset on cooling. Therefore, the $T_{L}$ values chosen for the optimization of the liquidus were taken to be the highest value of the range. The $\mathrm{T}_{\mathrm{S}}$ values from Table II were not used in the optimization because they are considered to be less accurate than the liquidus values.

The VOM 'first observation of melting' temperatures given in the last two columns of Table II are within $8 \mathrm{~K}$ of the selected solidus temperatures from the DTA measurements. As is clearly seen in Fig. 3 of sample I quenched from $\mathrm{T}=1733 \mathrm{~K}$, the liquid phase only occurs at the grain boundaries where melting is always initiated, while the bulk of the sample remains intact. Similarly, the VOM "collapsing" temperatures fall between the selected liquidus and solidus temperatures for each alloy in agreement with the notion that collapse would be expected before melting is complete.

\section{Characterization after thermal analysis}

Post-solidification microstructural analysis was performed on samples I-III after VOM and DTA to identify the composition corresponding to the B2 congruent melting. Two fundamentally different solidification paths occur for the alloys depending on their composition relative to this congruent point. Initial compositions on the Co-rich side will contain cobalt enrichment of the 
remaining liquid as solidification proceeds with possible formation of $\mathrm{C} 15, \mathrm{C} 36, \mathrm{~L}_{2}$, and $\mathrm{A} 1$ phases. On the contrary, alloys on the Ti-rich side yield Ti-rich compositions on solidification, possibly forming $\mathrm{CoTi}_{2}$ and/or A2 phases.

$\mathrm{XRD}$ and SEM/EDS analyses have unambiguously confirmed that alloys I and II are on the Co-rich and alloy III is on the Ti-rich side of the congruent melting point. The XRD pattern of sample I (Fig. 4), in addition to the B2 reflections, shows two peaks corresponding to the strongest reflections of the $\mathrm{C} 15$ phase. Accordingly, sample I has an additional thermal arrest at $1513 \mathrm{~K}$ on its DTA cooling curve (Fig.2) that likely corresponds to the peritectic reaction: B2 + liquid $\rightarrow \mathrm{C} 15$. This value compares to the values of $1506 \mathrm{~K}$ and $1523 \mathrm{~K}$ determined for this reaction by Pet'kov and Kireev ${ }^{[11]}$ and by Zakharov and Livshitz. ${ }^{[22]}$ Fig. 5a for alloy II shows that compositional segregation is clearly visible with solidified liquid enriched with Co and the formation of $\mathrm{C} 15\left(\mathrm{Co}_{2} \mathrm{Ti}\right)$ particles in the lighter areas. Similar segregation results were observed for alloy I. Fig. 5b for alloy III also shows compositional segregation but with solidified liquid enriched with $\mathrm{Ti}$ and the formation of $\mathrm{A} 2$ particles in the darker areas (no $\mathrm{CoTi}_{2}$ particles were found in alloy III perhaps due to the small temperature range of the $\mathrm{CoTi}_{2}$ liquidus and a failure to nucleate during quenching). The different segregation patterns in alloys I and II vs. alloy III strongly support our conclusion that the congruent melting composition is close to the stoichiometric composition and lies between 49.4 and 50.4 at pct Ti.

The combination of the DTA and VOM results clearly indicate that the previously determined values in the range of $1600 \mathrm{~K}$ for the $\mathrm{B} 2$ congruent point are incorrect. The newly determined B2 liquidus temperatures and compositions near the congruent melting point, as summarized in Table II and shown in Fig. 1, were next used in the thermodynamic assessment of the Co-Ti system. 


\section{THERMODYNAMIC MODELING}

\section{A. Evaluation of the experimental data}

A summary of the experimental data available for the Co-Ti system along with the investigative techniques is given in Table III. The last column indicates whether the data were selected for the present thermodynamic assessment. The evaluation of the Co-Ti system by Murray $^{[5]}$ includes publications until 1983. Since 1983, no experimental information was published on phase equilibria, but there were several studies published on thermochemical properties included in Table III.

\section{Phase Diagram}

All of the phase diagram data from the literature and the experimental results obtained in this work are shown in Fig. 1. Ti-rich liquidus ( $>50$ at pet Ti) data are very scarce with no experimental points for compositions above 75 at pct Ti. As discussed in Section IIA, the most controversial data are for the maximum melting point of the B2 phase with the discrepancy being likely associated with alloy contamination by the interstitial elements $(\mathrm{O}, \mathrm{C}, \mathrm{N})$ and with the offcongruent composition issues. As described in Section IIC, we have minimized the potential effects on the $T_{m}$ value by conducting experiments in controlled ambient atmosphere and by monitoring overall composition and the contamination levels in processed Co-Ti alloys. We found that the maximum melting temperature of $1776 \mathrm{~K} \pm 5 \mathrm{~K}$ corresponds to the nearstoichiometric composition. This $\mathrm{T}_{\mathrm{m}}$ value is only $35 \mathrm{~K}$ lower than the highest reported $\mathrm{B} 2$ melting temperature ${ }^{[11]}$ but more than $180 \mathrm{~K}$ higher than the "low limit" $\mathrm{T}_{\mathrm{m}}$ data. ${ }^{[6,7]}$

Literature data on the solubility limits of the B2 phase on the Co-rich side at $\mathrm{T}>1400 \mathrm{~K}$ are also uncertain. The phase boundary was found to be 41.8 at pct Ti at $1413 \mathrm{~K}^{[21]}$ by EPMA method versus 45 to 46 at pet $\mathrm{Ti}^{[6,11]}$ determined from XRD and metallographic analyses. In our assessment, higher weight was assigned for the latter sets of data by Iannucci et al. ${ }^{[6]}$ and by 
Pet'kov and Kireev ${ }^{[11]}$ due to their use of direct high-temperature XRD observations of the oneand two-phase fields in the vicinity of the B2 homogeneity region. Lower weight was assigned to all of the datasets from van der Straten et al. ${ }^{[21]}$ because of their overestimation of the A1 solvus boundary as discussed in the next paragraph.

The homogeneity ranges of the $\mathrm{A} 2, \mathrm{CoTi}_{2}, \mathrm{C} 15, \mathrm{C} 36, \mathrm{L1}_{2}$, and $\mathrm{A} 1$ are well defined in the literature, with two exceptions. The first is uncertainty associated with the $(\mathrm{C} 15+\mathrm{C} 36)$ twophase field, which is difficult to measure accurately due to the very narrow compositional gap $(<$ 1 at pct) between the co-existing Laves phases. ${ }^{[21]}$ The second is uncertainty associated with the low temperature A1 phase boundary. A gradual reduction of the titanium terminal solubility in the A1 phase with decreasing temperature reported by van der Straten et al. ${ }^{[21]}$ and by Zakharov and Livshitz ${ }^{[22]}$ is contradicted by the abrupt change in the A1 solvus line below $\approx 1173 \mathrm{~K}$ according to Fountain and Forgeng ${ }^{[23]}$ and Takayama et al. ${ }^{[24]}$ A systematic study ${ }^{[24]}$ has demonstrated that the anomaly in the Ti solubility in A1 is typical for the Co-M systems $(\mathrm{M}=$ $\mathrm{Al}, \mathrm{Mo}, \mathrm{Ti}$, and $\mathrm{W}$ ) and is caused by the para-to-ferromagnetic transformations in the A1 phase. Therefore, the "gradual" Ti solubility data ${ }^{[21,22]}$ in the $\mathrm{A} 1$ phase at $\mathrm{T}<1100 \mathrm{~K}$ were excluded from the assessment in favor of the retrograde A1 solvus data below this temperature. ${ }^{[23,24]}$ The estimates of the A1 phase boundary by Fountain and Forgeng ${ }^{[23]}$ and by Takayama et al. ${ }^{[24]}$ (Fig. 6) differ by about 3 at pct. Fountain and Forgeng ${ }^{[23]}$ employed a direct XRD observation of one(A1) and two- $\left(\mathrm{A} 1+\mathrm{L1}_{2}\right)$ phase fields, while Takayama et al. ${ }^{[24]}$ may have overestimated the Ti solubility limits in the $\mathrm{A} 1$ phase by using the lattice parameter method for the $\left(\mathrm{A} 1+\mathrm{L}_{2}\right)$ mixture. Zhao ${ }^{[25]}$ suggested that the possibility of not reaching equilibrium in study of Takayama et $a .^{[24]}$ could be a contributing factor in overestimating the Ti content of the A1 solvus boundary. Thus, a higher weight was assigned to the data of Fountain and Forgeng. ${ }^{[23]}$ 
Experimental measurements of the concentration dependence of the Curie temperature $\left(T_{c}\right)$ for the A1 phase revealed a strong negative deviation from the linear $T_{c}=1396 \cdot x_{C_{0}}$ behavior (Fig. 7). All the experimental data from Table III were used as input to the optimization in the present assessment to fit the $T_{c}$ concentration dependence.

The melting behavior of the two Laves phases, C36 and C15, and their associated invariant equilibria temperatures require further experimental verification. Based on limited DTA results, Wallbaum ${ }^{[8]}$ made an assumption that the $\mathrm{C} 36$ phase undergoes a solid-solid transformation on heating to the $\mathrm{C} 15$ structure with the $\mathrm{C} 15$ phase melting congruently at $1523 \mathrm{~K}$. On the contrary, in the more recent and detailed study by Pet'kov and Kireev, ${ }^{[11]}$ it was found that both C36 and C15 phases melt incongruently at 1483 and $1508 \mathrm{~K}$, respectively. The melting behavior for the Laves phases from Pet'kov and Kireev ${ }^{[1]}$ was adopted for the present assessment.

\section{Thermochemical data}

Thermochemical experimental data are summarized in Table III and include the formation enthalpy, $\Delta^{\mathrm{f}} \mathrm{H}$, for the intermetallics (Fig. 8) and the enthalpy of mixing, $\Delta^{\mathrm{mix}} \mathrm{H}$, in the liquid (Fig. 9). All the studies used calorimetric methods to measure the $\Delta^{\mathrm{f}} \mathrm{H}$ of the solid phases except for Balarin and Bartsch. ${ }^{[26]}$ They used an indirect method for estimating $\Delta^{\mathrm{f}} \mathrm{H}$ for the $\mathrm{L} 1_{2}$ phase from the conversion rate of the reaction: $\mathrm{Co}$ (solid) $+\mathrm{TiCl}_{4}$ (gas) $+\mathrm{H}_{2}$ (gas) $\rightarrow \mathrm{Co}_{3} \mathrm{Ti}$ (solid) + other products. This value was given lower weight in our assessment due to: a) potential uncertainly of the thermochemical data for the gaseous species involved in this reaction; b) the difficultly of obtaining the exact amount of the $\mathrm{L} 1_{2}$ phase formed in the above reaction.

There are no experimental data for the $\mathrm{CoTi}_{2}$ formation enthalpy, and the value of $-33 \mathrm{~kJ} / \mathrm{mol}$ computed from the Miedema method ${ }^{[27]}$ was used as an estimate. 
For the liquid properties, solution calorimetry was used to measure $\Delta^{\mathrm{mix}} \mathrm{H}$ at 1823 to 2000 $\mathrm{K},{ }^{[28-30]}$ and Knudsen cell mass-spectrometry was employed to determine activities in the Co-Ti melts between 1850 and $2020 \mathrm{~K} \cdot{ }^{[31]}$ In the latter work by Ueda et al., the integral enthalpy of mixing derived from the activity data was as much as 40 pct lower than the data from Esin et $a l .{ }^{[29]}$ and Wang et al. ${ }^{[30]}$ Ueda et al. noted oxygen contamination of their liquid alloys, which increased with Ti content. This fact prompted us to eliminate the data of Ueda et al. ${ }^{[31]}$ from the assessment. In addition, the integral mixing enthalpies reported by Wang et al. ${ }^{[30]}$ were converted for more accuracy to the incremental enthalpy changes that were originally measured by the authors in the solution calorimeter.

\section{B. Models}

\section{Analytical description of the phases}

Gibbs energy expressions for the pure elements in their standard states were described as follows:

$$
{ }^{\circ} \mathrm{G}_{i}^{\Phi}(\mathrm{T})-\mathrm{H}_{\mathrm{i}}^{\mathrm{SER}}=\mathrm{A}_{\mathrm{i}}^{\Phi}+\mathrm{B}_{\mathrm{i}}^{\Phi} \mathrm{T}+\mathrm{C}_{\mathrm{i}}^{\Phi} \mathrm{T} \ln \mathrm{T}+\mathrm{D}_{\mathrm{i}}^{\Phi} \mathrm{T}^{2}+\mathrm{E}_{\mathrm{i}}^{\Phi} \mathrm{T}^{-1}+\mathrm{F}_{\mathrm{i}}^{\Phi} \mathrm{T}^{3}+\mathrm{I}_{\mathrm{i}}^{\Phi} \mathrm{T}^{7}+\mathrm{J}_{\mathrm{i}}^{\Phi} \mathrm{T}^{-9}
$$

where $\mathrm{H}_{\mathrm{i}}^{\mathrm{SER}}$ ("SER" stands for Standard Element Reference) are the enthalpy values for components in their stable forms at $10^{5} \mathrm{~Pa}$ and $298.15 \mathrm{~K}$. The values of the thermodynamic coefficients $\mathrm{A}_{\mathrm{i}}^{\Phi}$ through $\mathrm{J}_{\mathrm{i}}^{\Phi}$ were taken from the SGTE databank. ${ }^{[32]}$

Initial model choices for the solution and intermetallic phases and the results of the preliminary assessment were first reported by Davydov et al. ${ }^{[33]}$ The model descriptions of and final values of re-optimized parameters are summarized in Table IV. The liquid phase, the A1, A2, and A3 solid solutions were modeled as disordered phases using a Redlich-Kister polynomial $^{[34]}$ to describe their excess Gibbs energies. The total Gibbs energy for the above 
phases is represented by the reference ${ }^{(\text {ref })}$, ideal ${ }^{(\mathrm{id})}$, excess ${ }^{(\mathrm{ex})}$, and the magnetic ${ }^{(\mathrm{magn})}$ parts in terms of one mole of atoms:

$$
\mathrm{G}^{\Phi}={ }^{\mathrm{ref}} \mathrm{G}^{\Phi}+{ }^{\mathrm{id}} \mathrm{G}^{\Phi}+{ }^{\mathrm{ex}} \mathrm{G}^{\Phi}+{ }^{\mathrm{magn}} \mathrm{G}^{\Phi}
$$

where ${ }^{\text {ref }} \mathrm{G}^{\Phi}=\mathrm{x}_{\mathrm{Co}}{ }^{\circ} \mathrm{G}_{\mathrm{Co}}^{\Phi}+\mathrm{x}_{\mathrm{Ti}}{ }^{\circ} \mathrm{G}_{\mathrm{Ti}}^{\Phi}$

$$
\begin{aligned}
& { }^{\mathrm{id}} \mathrm{G}^{\Phi}=\mathrm{RT}\left(\mathrm{x}_{\mathrm{Co}} \ln \mathrm{x}_{\mathrm{Co}}+\mathrm{x}_{\mathrm{Ti}} \ln \mathrm{x}_{\mathrm{Ti}}\right) \\
& { }^{\mathrm{ex}} \mathrm{G}^{\Phi}=\mathrm{x}_{\mathrm{Co}} \mathrm{x}_{\mathrm{Ti}} \sum_{\mathrm{n}}{ }^{\mathrm{n}} \mathrm{L}_{\mathrm{Co}, \mathrm{Ti}}^{\Phi}\left(\mathrm{x}_{\mathrm{Co}}-\mathrm{x}_{\mathrm{Ti}}\right)^{\mathrm{n}}
\end{aligned}
$$

The magnetic contribution ${ }^{\text {magn }} \mathrm{G}^{\Phi}$ to the Gibbs energy of the A1, A2, and A3 solution phases in ferro- and paramagnetic states is described after Dinsdale ${ }^{[32]}$ and Hillert and Jarl ${ }^{[35]}$ as:

$$
{ }^{\operatorname{magn}} \mathrm{G}^{\Phi}=\mathrm{RT} \ln (\beta+1) \mathrm{f}(\tau)
$$

where $\tau=\mathrm{T} / \mathrm{T}_{\mathrm{c}}, \mathrm{T}_{\mathrm{c}}$ is the Curie temperature, and $\beta$ is the effective magnetic moment per atom. The function $\mathrm{f}(\tau)$ for both $\mathrm{A} 1$ and $\mathrm{A} 3$ phases is given by:

$$
\begin{aligned}
& f(\tau)=1-0.86034 \tau^{-1}-0.17449 \tau^{3}-0.007755 \tau^{9}-0.001745 \tau^{15} \text { for } \tau \leq 1 \\
& f(\tau)=-0.04269 \tau^{-5}-0.001355 \tau^{-15}-0.000285 \tau^{-25} \text { for } \tau>1
\end{aligned}
$$

and for the A2 phase it is described as:

$$
\begin{aligned}
& f(\tau)=1-0.90530 \tau^{-1}-0.15301 \tau^{3}-0.006800 \tau^{9}-0.001530 \tau^{15} \text { for } \tau \leq 1 \\
& f(\tau)=-0.06417 \tau^{-5}-0.0020372 \tau^{-15}-0.000428 \tau^{-25} \text { for } \tau>1
\end{aligned}
$$

The concentration dependencies of the $T_{c}$ and $\beta$ are expressed as follows:

$$
\mathrm{T}_{\mathrm{c}}^{\Phi}=\mathrm{x}_{\mathrm{Co}} \mathrm{T}_{\mathrm{Co}}^{\Phi}+\mathrm{x}_{\mathrm{Co}} \mathrm{x}_{\mathrm{Ti}} \mathrm{T}_{\mathrm{Co}, \mathrm{Ti}}^{\Phi}
$$

and $\beta^{\Phi}=\mathrm{x}_{\mathrm{Co}} \beta_{\mathrm{Co}}^{\Phi}+\mathrm{x}_{\mathrm{Co}} \mathrm{x}_{\mathrm{Ti}} \beta_{\mathrm{Co}, \mathrm{Ti}}^{\Phi}$ 
where $\Phi$ denotes $\mathrm{A} 1, \mathrm{~A} 2$, or $\mathrm{A} 3$ phases, $\mathrm{T}_{\mathrm{Co}}^{\Phi}$ and $\beta_{\mathrm{Co}}^{\Phi}$ refer to the pure Co values, and $\mathrm{T}_{\mathrm{Co}, \mathrm{Ti}}^{\Phi}$ and $\beta_{\mathrm{Co}, \mathrm{Ti}}^{\Phi}$ are adjustable parameters, evaluated as described below in the "Optimization of model parameters" section. For pure Ti values $\mathrm{T}_{\mathrm{c}}^{\Phi}$ and $\beta^{\Phi}$ become zero.

For the intermetallics, the $\mathrm{CoTi}_{2}$ phase was treated as a line compound due to its narrow, less than 0.1 at pct $\mathrm{Ti},{ }^{[36]}$ homogeneity range. Its Gibbs energy is described as:

$$
\mathrm{G}^{\mathrm{COTi2}}={ }^{\circ} \mathrm{G}_{\mathrm{Co}}^{\mathrm{A} 3}+2^{\circ} \mathrm{G}_{\mathrm{Ti}}^{\mathrm{A} 3}+\Delta^{\mathrm{f}} \mathrm{G}^{\mathrm{CoTi} 2}
$$

where $\Delta^{\mathrm{f}} \mathrm{G}^{\mathrm{COTi} 2}$ is the Gibbs energy of formation of this compound and is represented as $\Delta^{\mathrm{f}} \mathrm{G}^{\mathrm{COTi2}}=\mathrm{a}+\mathrm{bT}$, with adjustable $a$ and $b$ parameters.

The remaining four phases, $\mathrm{B} 2, \mathrm{C} 15, \mathrm{C} 36$, and $\mathrm{L}_{2}$, were described by a sublattice (SL) formalism, also designated as a compound energy formalism (CEF) ${ }^{[37]}$ to accommodate their substantial homogeneity ranges. Two versions of the CEF were applied. A simple SL description was used to model the $\mathrm{C} 15, \mathrm{C} 36$, and $\mathrm{B} 2$ phases. In addition, the modified sublattice formalism $(\mathrm{MSL})^{[38]}$ was used to describe the $\mathrm{B} 2$ and the $\mathrm{L} 1_{2}$ phases. The alternative representation of the B2 phase by SL and MSL models allows the descriptions to be used interchangeably in combination with various databases for extrapolation into higher order systems.

The Laves phases, $\mathrm{C} 15$ and $\mathrm{C} 36$, were modeled using a two-sublattice $(\mathrm{Co}, \mathrm{Ti})_{2}(\mathrm{Co}, \mathrm{Ti})$ model with the following generalized Gibbs energy expression:

$$
\begin{aligned}
& \mathrm{G}^{\mathrm{Laves}}=\mathrm{RT}\left\{2\left(\mathrm{y}_{\mathrm{Co}}^{1} \ln \mathrm{y}_{\mathrm{Co}}^{1}+\mathrm{y}_{\mathrm{Ti}}^{1} \ln \mathrm{y}_{\mathrm{Ti}}^{1}\right)+\left(\mathrm{y}_{\mathrm{Co}}^{2} \ln \mathrm{y}_{\mathrm{Co}}^{2}+\mathrm{y}_{\mathrm{Ti}}^{2} \ln \mathrm{y}_{\mathrm{Ti}}^{2}\right)\right\}+\mathrm{y}_{\mathrm{Co}}^{1} \mathrm{y}_{\mathrm{Co}}^{2}{ }^{\circ} \mathrm{G}_{\mathrm{Co}: \mathrm{Co}}^{\mathrm{Laves}} \\
& +\mathrm{y}_{\mathrm{Co}}^{1} \mathrm{y}_{\mathrm{Ti}}^{2}{ }^{\circ} \mathrm{G}_{\mathrm{Co}: \mathrm{Ti}}^{\mathrm{Laves}}+\mathrm{y}_{\mathrm{Ti}}^{1} \mathrm{y}_{\mathrm{Co}}^{2}{ }^{\circ} \mathrm{G}_{\mathrm{Ti}}^{\mathrm{Li} C \mathrm{Co}}+\mathrm{y}_{\mathrm{Ti}}^{1} \mathrm{y}_{\mathrm{Ti}}^{20} \mathrm{G}_{\mathrm{Ti}}^{\mathrm{Laves}}+\mathrm{y}_{\mathrm{Co}}^{1} \mathrm{y}_{\mathrm{Co}}^{2} \mathrm{y}_{\mathrm{Ti}}^{2}{ }^{0} \mathrm{~L}_{\mathrm{Co}: \mathrm{Co}, \mathrm{Ti}}^{\mathrm{Laves}}+ \\
& \mathrm{y}_{\mathrm{Ti}}^{1} \mathrm{y}_{\mathrm{Co}}^{2} \mathrm{y}_{\mathrm{Ti}}^{2}{ }^{0} \mathrm{~L}_{\mathrm{Ti}: \mathrm{Co}, \mathrm{Ti}}^{\mathrm{Laves}}+\mathrm{y}_{\mathrm{Co}}^{1} \mathrm{y}_{\mathrm{Ti}}^{1} \mathrm{y}_{\mathrm{Co}}^{2} \mathrm{~L}_{\mathrm{Co}, \mathrm{Ti}: \mathrm{Co}}^{\mathrm{Laves}}+\mathrm{y}_{\mathrm{Co}}^{1} \mathrm{y}_{\mathrm{Ti}}^{1} \mathrm{y}_{\mathrm{Ti}}^{2}{ }^{0} \mathrm{~L}_{\mathrm{Co}, \mathrm{Ti}: \mathrm{Ti}}^{\mathrm{Laves}}
\end{aligned}
$$


where $y_{i}^{1}$ and $y_{i}^{2}$ are the site fractions of component $i$ on sublattice ${ }^{1}$ or ${ }^{2}$, coefficients ${ }^{\circ} \mathrm{G}_{\mathrm{i}: \mathrm{j}}^{\mathrm{Laves}}$ are Gibbs energies of the respective end-member phases, which can be viewed as hypothetical compounds with the $\mathrm{C} 15$ or $\mathrm{C} 36$ structure with species $\mathrm{i}$ and $\mathrm{j}$ ( $\mathrm{i}=\mathrm{Co}, \mathrm{Ti} ; \mathrm{j}=\mathrm{Co}, \mathrm{Ti}$ ) occupying respective sublattices. The quantities ${ }^{\circ} \mathrm{G}_{\mathrm{i}: \mathrm{j}}$ are expressed as:

$$
{ }^{\mathrm{o}} \mathrm{G}_{\mathrm{i}: \mathrm{j}}^{\text {Laves }}=2^{\mathrm{o}} \mathrm{G}_{\mathrm{i}}^{\mathrm{A3}}+{ }^{\mathrm{o}} \mathrm{G}_{\mathrm{j}}^{\mathrm{A3}}+\Delta^{\mathrm{f}} \mathrm{G}_{\mathrm{i}: \mathrm{j}}^{\text {Laves }}
$$

with $\Delta^{\mathrm{f}} \mathrm{G}_{\mathrm{i}: \mathrm{j}}^{\text {Laves }}=\mathrm{a}+\mathrm{bT}$, where a and $\mathrm{b}$ are adjustable parameters.

The remaining terms, ${ }^{0} \mathrm{~L}_{\mathrm{i}, \mathrm{j}}^{\text {Laves }}$, are interaction parameters between the components on the same sublattice.

For the B2 phase, an asymmetrical SL model $(\mathrm{Co}, \mathrm{Va})(\mathrm{Co}, \mathrm{Ti})$ was chosen, assuming vacancy (Va) formation on the first sublattice, and $\mathrm{Co} \leftrightarrow \mathrm{Ti}$ substitution on the other. $\mathrm{XRD}^{[39]}$ and density $^{[40]}$ measurements have unambiguously shown that the wide homogeneity range on the Co-rich side is the result of substitution on the second sublattice. Since no experimental information on the mechanism of deviation from stoichiometry on the Ti-rich side is available, a vacancy formation mechanism on the first sublattice was chosen for the sake of compatibility with the other B2 descriptions, such as in the Ni-Al system. ${ }^{[38]}$ The Gibbs energy expression for the B2 phase is similar to the Laves phases description:

$$
\begin{aligned}
& \mathrm{G}^{\mathrm{B} 2}=\mathrm{RT}\left(\mathrm{y}_{\mathrm{Co}}^{1} \ln \mathrm{y}_{\mathrm{Co}}^{1}+\mathrm{y}_{\mathrm{Va}}^{1} \ln \mathrm{y}_{\mathrm{Va}}^{1}+\mathrm{y}_{\mathrm{Co}}^{2} \ln \mathrm{y}_{\mathrm{Co}}^{2}+\mathrm{y}_{\mathrm{Ti}}^{2} \ln \mathrm{y}_{\mathrm{Ti}}^{2}\right)+\mathrm{y}_{\mathrm{Co}}^{1} \mathrm{y}_{\mathrm{Co}}^{2}{ }^{o} \mathrm{G}_{\mathrm{Co}: \mathrm{Co}}^{\mathrm{B} 2} \\
& +\mathrm{y}_{\mathrm{Co}}^{1} \mathrm{y}_{\mathrm{Ti}}^{2}{ }^{0} \mathrm{G}_{\mathrm{Co}: \mathrm{Ti}}^{\mathrm{B} 2}+\mathrm{y}_{\mathrm{Va}}^{1} \mathrm{y}_{\mathrm{Co}}^{2}{ }^{0} \mathrm{G}_{\mathrm{Va}: \mathrm{Co}}^{\mathrm{B} 2}+\mathrm{y}_{\mathrm{Va}}^{1} \mathrm{y}_{\mathrm{Ti}}^{2}{ }^{0} \mathrm{G}_{\mathrm{Va}: \mathrm{Ti}}^{\mathrm{B} 2}+\mathrm{y}_{\mathrm{Co}}^{1} \mathrm{y}_{\mathrm{Co}}^{2} \mathrm{y}_{\mathrm{Ti}}^{2}{ }^{0} \mathrm{~L}_{\mathrm{Co}: \mathrm{Co}, \mathrm{Ti}}^{\mathrm{B} 2}+ \\
& \mathrm{y}_{\mathrm{Va}}^{1} \mathrm{y}_{\mathrm{Co}}^{2} \mathrm{y}_{\mathrm{Ti}}^{2}{ }^{0} \mathrm{~L}_{\mathrm{Va}: \mathrm{Co}, \mathrm{Ti}}^{\mathrm{B} 2}+\mathrm{y}_{\mathrm{Co}}^{1} \mathrm{y}_{\mathrm{Va}}^{1} \mathrm{y}_{\mathrm{Co}}^{2}{ }_{0}^{0} \mathrm{~L}_{\mathrm{Co}, \mathrm{Va}: \mathrm{Co}}^{\mathrm{B}}+\mathrm{y}_{\mathrm{Co}}^{1} \mathrm{y}_{\mathrm{Va}}^{1} \mathrm{y}_{\mathrm{Ti}}^{2}{ }^{0} \mathrm{~L}_{\mathrm{Co}, \mathrm{Va}: \mathrm{Ti}}^{\mathrm{B} 2}
\end{aligned}
$$

where ${ }^{o} G_{i: j}^{B 2}={ }^{o} G_{i}^{A 2}+{ }^{o} G_{j}^{A 2}+\Delta{ }^{f} G_{i: j}^{B 2}$

with parameters $\Delta^{\mathrm{f}} \mathrm{G}_{\mathrm{i}: \mathrm{j}}^{\mathrm{B} 2}=\mathrm{a}+\mathrm{bT}$ being optimized. 
Since B2 is an ordered form of the A2 disordered phase, this phase was also described using the MSL model with two symmetric sublattices $(\mathrm{Co}, \mathrm{Ti}, \mathrm{Va})_{0.5}(\mathrm{Co}, \mathrm{Ti}, \mathrm{Va})_{0.5}$. This model and its relation to the standard SL formalism are described in detail by Ansara et al. ${ }^{[38]}$ and Dupin and Ansara $^{[41]}$. In short, the MSL Gibbs energy expression for B2 is split into a disordered part describing the A2 state and two terms describing ordering:

$$
\mathrm{G}^{\mathrm{B} 2}={ }^{\mathrm{dis}} \mathrm{G}^{\mathrm{A} 2}\left(\mathrm{x}_{\mathrm{i}}\right)+{ }^{\text {ord }} \mathrm{G}^{\mathrm{B} 2}\left(\mathrm{y}_{\mathrm{i}}^{1}, \mathrm{y}_{\mathrm{i}}^{2}\right)-{ }^{\text {ord }} \mathrm{G}^{\mathrm{B} 2}\left(\mathrm{x}_{\mathrm{i}}\right)
$$

where mole fraction $\mathrm{x}_{\mathrm{i}}$ and the site fractions $\mathrm{y}_{\mathrm{i}}^{1}$ and $\mathrm{y}_{\mathrm{i}}^{2}$ per lattice site of component $i(i=\mathrm{Co}, \mathrm{Ti}$, Va) are related through $x_{i}=0.5\left(y_{i}^{1}+y_{i}^{2}\right)$. When B2 disorders into the A2 state (i.e. $\left.y_{i}^{1}=y_{i}^{2}=x_{i}\right)$, the second and third terms in Eq. [18] cancel each other, leaving only ${ }^{\text {dis }} \mathrm{G}^{\mathrm{A} 2}\left(\mathrm{x}_{\mathrm{i}}\right)$ term described after Eq. [2]. Gibbs energy for the ordered part is described as following (only non-zero terms from the present assessment are listed):

$$
\begin{aligned}
& { }^{\text {ord }} \mathrm{G}^{\mathrm{B} 2}\left(\mathrm{y}_{\mathrm{i}}^{1}, \mathrm{y}_{\mathrm{i}}^{2}\right)=0.5 \mathrm{RT}\left(\mathrm{y}_{\mathrm{Co}}^{1} \ln \mathrm{y}_{\mathrm{Co}}^{1}+\mathrm{y}_{\mathrm{Ti}}^{1} \ln \mathrm{y}_{\mathrm{Ti}}^{1}+\mathrm{y}_{\mathrm{Va}}^{1} \ln \mathrm{y}_{\mathrm{Va}}^{1}+\mathrm{y}_{\mathrm{Co}}^{2} \ln \mathrm{y}_{\mathrm{Co}}^{2}+\mathrm{y}_{\mathrm{Ti}}^{2} \ln \mathrm{T}_{\mathrm{Ti}}^{2}+\right. \\
& \left.\mathrm{y}_{\mathrm{Va}}^{2} \ln _{\mathrm{Va}}^{2}\right)+\mathrm{y}_{\mathrm{Co}}^{1} \mathrm{y}_{\mathrm{Ti}}^{2} \mathrm{G}_{\mathrm{Co}: \mathrm{Ti}}^{\mathrm{B} 2}+\mathrm{y}_{\mathrm{Ti}}^{1} \mathrm{y}_{\mathrm{Co}}^{2} \mathrm{G}_{\mathrm{Ti}: \mathrm{Co}}^{\mathrm{B} 2}+\mathrm{y}_{\mathrm{Co}}^{1} \mathrm{y}_{\mathrm{Va}}^{2} \mathrm{G}_{\mathrm{Co}: \mathrm{Va}}^{\mathrm{B} 2}+\mathrm{y}_{\mathrm{Va}}^{1} \mathrm{y}_{\mathrm{Co}}^{2} \mathrm{G}_{\mathrm{Va}: \mathrm{Co}}^{\mathrm{B} 2}+ \\
& \mathrm{y}_{\mathrm{Ti}}^{1} \mathrm{y}_{\mathrm{Va}}^{2} \mathrm{G}_{\mathrm{Ti}: \mathrm{Va}}^{\mathrm{B} 2}+\mathrm{y}_{\mathrm{Va}}^{1} \mathrm{y}_{\mathrm{Ti}}^{2} \mathrm{G}_{\mathrm{Va}: \mathrm{Ti}}^{\mathrm{B} 2}+\mathrm{y}_{\mathrm{Co}}^{1} \mathrm{y}_{\mathrm{Ti}}^{1} \mathrm{y}_{\mathrm{Ti}}^{2} \mathrm{~L}_{\mathrm{Co}, \mathrm{Ti}: \mathrm{Ti}}^{\mathrm{B} 2}+\mathrm{y}_{\mathrm{Ti}}^{1} \mathrm{y}_{\mathrm{Co}}^{2} \mathrm{y}_{\mathrm{Ti}}^{2}{ }^{0} \mathrm{~L}_{\mathrm{Ti}: \mathrm{Co}, \mathrm{Ti}}^{\mathrm{B} 2}+ \\
& \mathrm{y}_{\mathrm{Co}}^{1} \mathrm{y}_{\mathrm{Ti}}^{1} \mathrm{y}_{\mathrm{Co}}^{2}{ }^{0} \mathrm{~L}_{\mathrm{Co}, \mathrm{Ti}: \mathrm{Co}}^{\mathrm{B} 2}+\mathrm{y}_{\mathrm{Co}}^{1} \mathrm{y}_{\mathrm{Co}}^{2} \mathrm{y}_{\mathrm{Ti}}^{2}{ }^{0} \mathrm{~L}_{\mathrm{Co}: \mathrm{Co}, \mathrm{Ti}}^{\mathrm{B} 2}+\mathrm{y}_{\mathrm{Co}}^{1} \mathrm{y}_{\mathrm{Ti}}^{1} \mathrm{y}_{\mathrm{Co}}^{2}\left(\mathrm{y}_{\mathrm{Co}}^{1}-\mathrm{y}_{\mathrm{Ti}}^{1}\right)^{1} \mathrm{~L}_{\mathrm{Co}, \mathrm{Ti}: \mathrm{Co}}^{\mathrm{B} 2} \\
& +\mathrm{y}_{\mathrm{Co}}^{1} \mathrm{y}_{\mathrm{Co}}^{2} \mathrm{y}_{\mathrm{Ti}}^{2}\left(\mathrm{y}_{\mathrm{Co}}^{2}-\mathrm{y}_{\mathrm{Ti}}^{2}\right)^{1} \mathrm{~L}_{\mathrm{Co}: \mathrm{Co}, \mathrm{Ti}}^{\mathrm{B} 2}
\end{aligned}
$$

The MSL model was also employed to describe the ordered $\mathrm{L}_{2}$ phase by adding contribution to the disordered A1 Gibbs energy. Details of the $\mathrm{L}_{2}$ modeling are described by Ansara and coauthors. ${ }^{[38,42]}$ The phase was represented by a two-sublattice model $(\mathrm{Co}, \mathrm{Ti})_{0.75}(\mathrm{Co}, \mathrm{Ti})_{0.25}$ with the Gibbs energy description split into a disordered part, ${ }^{\text {dis }} \mathrm{G}^{\mathrm{A1}}\left(\mathrm{x}_{\mathrm{i}}\right)$, described after Eq. [2]; and an 
ordered part, ${ }^{\text {ord }} \mathrm{G}^{\mathrm{L} 12}\left(\mathrm{y}_{\mathrm{i}}^{1}, \mathrm{y}_{\mathrm{i}}^{2}\right)-{ }^{\text {ord }} \mathrm{G}^{\mathrm{L} 12}\left(\mathrm{x}_{\mathrm{i}}\right)$, described as follows (only non-zero terms from the present assessment are listed):

$$
\begin{aligned}
& { }^{\text {ord }} \mathrm{G}^{\mathrm{L} 12}\left(\mathrm{y}_{\mathrm{i}}^{1}, \mathrm{y}_{\mathrm{i}}^{2}\right)=\mathrm{RT}\left\{0.75\left(\mathrm{y}_{\mathrm{Co}}^{1} \ln \mathrm{y}_{\mathrm{Co}}^{1}+\mathrm{y}_{\mathrm{Ti}}^{1} \ln \mathrm{y}_{\mathrm{Ti}}^{1}\right)+0.25\left(\mathrm{y}_{\mathrm{Co}}^{2} \ln \mathrm{y}_{\mathrm{Co}}^{2}+\mathrm{y}_{\mathrm{Ti}}^{2} \ln \mathrm{y}_{\mathrm{Ti}}^{2}\right)\right\}+ \\
& \mathrm{y}_{\mathrm{Co}}^{1} \mathrm{y}_{\mathrm{Ti}}^{2} \mathrm{G}_{\mathrm{Co}: \mathrm{Ti}}^{\mathrm{L} 12}+\mathrm{y}_{\mathrm{Ti}}^{1} \mathrm{y}_{\mathrm{Co}}^{2} \mathrm{G}_{\mathrm{Ti}: \mathrm{Co}}^{\mathrm{L} 2}+\mathrm{y}_{\mathrm{Co}}^{1} \mathrm{y}_{\mathrm{Ti}}^{1} \mathrm{y}_{\mathrm{Ti}}^{2} \mathrm{~L}_{\mathrm{Co}, \mathrm{Ti}: \mathrm{Ti}}^{\mathrm{L} 12}+\mathrm{y}_{\mathrm{Co}}^{1} \mathrm{y}_{\mathrm{Ti}}^{1} \mathrm{y}_{\mathrm{Co}}^{2}{ }^{0} \mathrm{~L}_{\mathrm{Co}, \mathrm{Ti}: \mathrm{Co}}^{\mathrm{L} 12}+ \\
& \mathrm{y}_{\mathrm{Co}}^{1} \mathrm{y}_{\mathrm{Ti}}^{1} \mathrm{y}_{\mathrm{Co}}^{2}\left(\mathrm{y}_{\mathrm{Co}}^{1}-\mathrm{y}_{\mathrm{Ti}}^{1}\right){ }^{1} \mathrm{~L}_{\mathrm{Co}, \mathrm{Ti}: \mathrm{Co}}^{\mathrm{L} 2}+\mathrm{y}_{\mathrm{Co}}^{1} \mathrm{y}_{\mathrm{Ti}}^{1} \mathrm{y}_{\mathrm{Ti}}^{2}\left(\mathrm{y}_{\mathrm{Co}}^{1}-\mathrm{y}_{\mathrm{Ti}}^{1}\right){ }^{1} \mathrm{~L}_{\mathrm{Co}, \mathrm{Ti}: \mathrm{Ti}}^{\mathrm{L} 12}+\mathrm{y}_{\mathrm{Co}}^{1} \mathrm{y}_{\mathrm{Co}}^{2} \mathrm{y}_{\mathrm{Ti}}^{2}\left(\mathrm{y}_{\mathrm{Co}}^{2}-\right. \\
& \mathrm{y}_{\mathrm{Ti}}^{2}{ }^{1} \mathrm{~L}_{\mathrm{Co}: \mathrm{Co}, \mathrm{Ti}}^{\mathrm{L} 12}+\mathrm{y}_{\mathrm{Ti}}^{1} \mathrm{y}_{\mathrm{Co}}^{2} \mathrm{y}_{\mathrm{Ti}}^{2}\left(\mathrm{y}_{\mathrm{Co}}^{2}-\mathrm{y}_{\mathrm{Ti}}^{2}\right){ }^{1} \mathrm{~L}_{\mathrm{Ti}: \mathrm{Co}, \mathrm{Ti}}^{\mathrm{L} 12}
\end{aligned}
$$

The excess energy contribution due to magnetic ordering was also included for both $\mathrm{L} 1_{2}$ and $\mathrm{B} 2$ phases in the MSL model using equations similar to Eq. [11].

\section{Optimization of model parameters}

Optimization of the Gibbs energy model parameters for the solution phases and the intermetallic compounds was carried out by fitting the included experimental data of Table III (marked "yes") with the software packages BINGSS, BINFKT ${ }^{[12]}$ and Thermo-Calc. ${ }^{[13]}$ For the optimization procedure, each set of data from Table III was weighted based on the accuracy of the experimental method used and the validity of the results as evaluated in Section IIIA.

Optimization of the coefficients in the Gibbs energy expressions was carried out in several consecutive steps. In the first step, the parameter values were determined only for the solution phases from the enthalpy of mixing data of the liquid (Fig. 9, not using the data of Ueda et al.

${ }^{[31]}$ ) and a hypothetical phase diagram, which was extrapolated from the equilibrium diagram with the assumption that no intermetallic phases were stable.

Once preliminary parameters for the solution phases were obtained, the second step introduced the intermetallic $\mathrm{L1}_{2}$, "Laves", B2, and $\mathrm{CoTi}_{2}$ phases. At first, they were treated as stoichiometric compounds with initial $\Delta^{\mathrm{f}} \mathrm{H}$ coefficients based on the experimental values from 
Fig. 8. At this stage, the "Laves" phase was assigned the $\mathrm{Co}_{2} \mathrm{Ti}$ composition without distinguishing the $\mathrm{C} 15$ and $\mathrm{C} 36$ phases.

In the third step, the compound energy models (SL for C15, C36, B2 and MSL for L1 $1_{2}$ ) were employed to account for the homogeneity ranges of these phases. Finally, the B2 phase was described with the MSL model as an alternative to SL description. Since conversion between the two models is not possible for this system due to reasons outlined by Dupin and Ansara, ${ }^{[41]}$ the MSL coefficients were optimized independently from the SL parameters.

Throughout the optimization, several assumptions were applied to different models in order to minimize the number of adjustable parameters. For the $\mathrm{A} 2$ phase, the ${ }^{0} \mathrm{~L}_{\mathrm{Ti}, \mathrm{Va}}^{\mathrm{A} 2}$ and ${ }^{0} \mathrm{~L}_{\mathrm{Co}, \mathrm{Va}}^{\mathrm{A} 2}$ parameters were fixed at 150 and $135 \mathrm{~kJ} / \mathrm{mol}$, respectively. These values were derived from the enthalpies of vacancy formation in pure titanium and cobalt ${ }^{[43]}$ by assuming equality of the slopes of the ${ }^{e x} \mathrm{G}_{\mathrm{i}, \mathrm{Va}}\left(\mathrm{x}_{\mathrm{i}}\right)$ curves near $\mathrm{x}_{\mathrm{i}}=1(\mathrm{i}=\mathrm{Co}$ or $\mathrm{Ti})$ to $\Delta^{\mathrm{f}} \mathrm{H}_{\mathrm{Va}}^{\mathrm{i}}$ values. The $\Delta^{\mathrm{f}} \mathrm{H}_{\mathrm{Va}}^{\mathrm{Ti}}=150$ $\mathrm{kJ} / \mathrm{mol}$ and $\Delta^{\mathrm{f}} \mathrm{H}_{\mathrm{Va}}^{\mathrm{Co}}=135 \mathrm{~kJ} / \mathrm{mol}$ formation enthalpies were derived by de Boer et al. ${ }^{[43]}$ from a semi-empirical "macroscopic atom" model based on the electron density distribution in metals. These values correlated well with the experimental estimates of the enthalpy of mono-vacancy formation in cobalt and titanium. ${ }^{[44]}$

As for the magnetic properties of the solution phases, the composition dependence of the Curie temperature for the A1 phase was determined by fitting the data of Fig. 7 to Eq. [11]. As a result, the value of $-1400 \mathrm{~K}$ was obtained for the $\mathrm{T}_{\mathrm{Co}, \mathrm{Ti}}^{\mathrm{Al}}$ coefficient. The same value $\mathrm{T}_{\mathrm{Co}, \mathrm{Ti}}^{\Phi}$ was applied to the other two solution phases, A2 and A3. The values of $\beta_{\mathrm{Co}, \mathrm{Ti}}^{\Phi}$ were set to zero for all solid solutions due to a lack of experimental data. 
For the Laves phases, the $\Delta^{\mathrm{f}} \mathrm{G}_{\text {Co:Co }}^{\text {Laves }}$ and $\Delta^{\mathrm{f}} \mathrm{G}_{\mathrm{Ti}: \mathrm{Ti}}^{\mathrm{Laves}}$ values from Eq. [15] were fixed to 15 $\mathrm{kJ} /$ mole in compliance with the rationale given by Dupin and Ansara. ${ }^{[4]}$ In addition, the following limitation was imposed on the $\Delta^{\mathrm{f}} \mathrm{G}_{\mathrm{Ti}: \mathrm{Co}}^{\text {Laves }}$ parameter: ${ }^{[45]}$

$$
\Delta^{\mathrm{f}} \mathrm{G}_{\mathrm{Ti}: \mathrm{Co}}^{\text {Laves }}=-\Delta^{\mathrm{f}} \mathrm{G}_{\mathrm{Co}: \mathrm{Ti}}^{\text {Laves }}+\Delta^{\mathrm{f}} \mathrm{G}_{\text {Co:Co }}^{\text {Laves }}+\Delta^{\mathrm{f}} \mathrm{G}_{\mathrm{Ti}: \mathrm{Ti}}^{\text {Lave }} .
$$

For the SL modeling of the B2 phase, all the parameters were adjusted during the optimization except for the $\Delta^{\mathrm{f}} \mathrm{G}_{\mathrm{Va}: \mathrm{Co}}^{\mathrm{B} 2},{ }^{0} \mathrm{~L}_{\mathrm{Co}, \mathrm{Va}: \mathrm{Va}}^{\mathrm{B} 2}$, and $\Delta^{\mathrm{f}} \mathrm{G}_{\mathrm{Va}}^{\mathrm{B} 2 \mathrm{Ti}}$ values. To be compatible with the alloy database developed by Dupin, ${ }^{[46]}$ these values were taken from the $\mathrm{Al}-\mathrm{Co}^{[46]}$ and $\mathrm{Ni}-\mathrm{Ti}^{[47]}$ assessments, respectively.

For the B2 SL model, the following restrictions can be imposed that are based on the B2 crystallographic symmetry: $G_{i: j}^{B 2}=G_{j: i}^{B 2}, L_{i, j: k}^{B 2}=L_{k: i, j}^{B 2}$. For the B2 MSL description the same relations were used in accordance with the work of Dupin and Ansara. ${ }^{[41]}$ In addition, $\mathrm{G}_{\mathrm{Co}: \mathrm{Va}}^{\mathrm{B} 2}(=$ $\left.\mathrm{G}_{\text {Va:Co }}^{\mathrm{B} 2}\right)$ and $\mathrm{G}_{\mathrm{Ti}: \mathrm{Va}}^{\mathrm{B} 2}\left(=\mathrm{G}_{\mathrm{Va:Ti}}^{\mathrm{B} 2}\right)$ were fixed at 67.5 and $75 \mathrm{~kJ} / \mathrm{mol}$, respectively, assuming equality to the energy of vacancies formation in the pure components. ${ }^{[43]}$ The magnetic parameter $\mathrm{T}_{\mathrm{Co}: \mathrm{Ti}}^{\mathrm{B} 2}$ $\left(=\mathrm{T}_{\mathrm{Ti}: \mathrm{Co}}^{\mathrm{B} 2}\right)$ in Eq. [11] was fixed at -500 value to decrease the $\mathrm{T}_{\mathrm{c}}$ temperature for the $\mathrm{B} 2$ phase.

Finally, using the constrains for the $\mathrm{L1}_{2} \mathrm{MSL}_{\text {model }}{ }^{[38]}$ and taking into account only the nonzero coefficients resulting from the optimization, the following relations were obtained for the $\mathrm{L}_{2}$ order parameters:

$$
\begin{aligned}
& \mathrm{G}_{\mathrm{Co}: \mathrm{Ti}}^{\mathrm{L} 12}=\mathrm{G}_{\mathrm{Ti}: \mathrm{Co}}^{\mathrm{L} 12}=3 \mathrm{U}_{1} \\
& { }^{0} \mathrm{~L}_{\mathrm{Co}, \mathrm{Ti}: \mathrm{Co}}^{\mathrm{L} 12}={ }^{0} \mathrm{~L}_{\mathrm{Co}, \mathrm{Ti}: \mathrm{Ti}}^{\mathrm{L} 12}=6 \mathrm{U}_{1} \\
& { }^{1} \mathrm{~L}_{\mathrm{Co}, \mathrm{Ti}: \mathrm{Co}}^{\mathrm{L} 12}={ }^{1} \mathrm{~L}_{\mathrm{Co}, \mathrm{Ti}: \mathrm{Ti}}^{\mathrm{L} 12}=3 \mathrm{U}_{4} \\
& { }^{1} \mathrm{~L}_{\mathrm{Co}: \mathrm{Co}, \mathrm{Ti}}={ }^{1} \mathrm{~L}_{\mathrm{Ti}: \mathrm{Co}, \mathrm{Ti}}=\mathrm{U}_{4} \\
& \mathrm{~T}_{\mathrm{Co}: \mathrm{Ti}}^{\mathrm{L} 12}=\mathrm{T}_{\mathrm{Ti}: \mathrm{Co}}^{\mathrm{L} 12}=3 \mathrm{~T}_{1}
\end{aligned}
$$




$$
\mathrm{T}_{\mathrm{Co}, \mathrm{Ti}: \mathrm{Co}}^{\mathrm{L} 12}=\mathrm{T}_{\mathrm{Co}, \mathrm{Ti}: \mathrm{Ti}}^{\mathrm{L} 12}=6 \mathrm{~T}_{1}
$$

Thus, only 3 independent coefficients, $\mathrm{U}_{1}, \mathrm{U}_{4}$ and $\mathrm{T}_{1}$, were adjusted in the $\mathrm{L}_{2}$ description during the optimization procedure.

Optimized parameters for all the phases are listed in Table IV. It should be noted that during the optimization, it was necessary to introduce terms with small coefficients, such as the $0.6 \mathrm{~T}$ temperature term of the $\mathrm{U}_{4}$ parameter in the $\mathrm{L1}_{2}$ MSL model. Although the contribution of this term to the Gibbs energy appears to be insignificant, it was essential to accurately reproduce the invariant equilibria involving the $\mathrm{L}_{2}$ phase.

\section{ASSESSMENT RESULTS AND DISCUSSION}

The parameters tabulated in Table IV were used to calculate the thermochemical properties and the phase diagram in Figures 6 - 11 and in Tables V and VI.

Figures 6,10 , and 11 show the calculated equilibrium phase diagram with the experimental data used in the assessment. The most significant differences between this work and other phase diagram assessments are: a) the value of the B2 congruent melting point, b) the description of Co-rich phase boundary of the B2 phase, and c) the location of the A1 solvus boundary. Different assessments and models used are also compared in Table I.

As experimentally determined in Section II, the maximum melting temperature for the B2 phase was evaluated to be $1776 \mathrm{~K} \pm 5 \mathrm{~K}$. $\mathrm{T}_{\mathrm{m}}$ values of 1774 at 50.2 at pct $\mathrm{Ti}$ and $1773 \mathrm{~K}$ at 49.8 at pct $\mathrm{Ti}$, calculated in this work using SL and MSL descriptions, respectively, lie within this experimental error. The B2 homogeneity range, calculated with SL and MSL models (Fig. 11), has a maximum width of 7.8 and 8.5 at pet at $1515 \mathrm{~K}$ and $1509 \mathrm{~K}$ peritectic temperatures, respectively. These widths are 1 to 3 at pct narrower than those from the assessments of Cacciamani et al. ${ }^{[19]}$ and Saunders and Miodownik ${ }^{[17]}$ at the corresponding peritectic 
temperatures. This difference is likely associated with the selection of the experimental data, with the sets of data from Iannucci et al. ${ }^{[6]}$ and from Pet'kov and Kireev ${ }^{[11]}$ being assigned a higher weight in the present work compared to data of van der Straten et al. ${ }^{[21]}$ as discussed in Section IIIA. Since both the SL and MSL models adequately describe the B2 homogeneity range and invariant equilibria involving the B2 phase within the experimental uncertainties (see Table VI and Fig. 11), these descriptions can be used interchangeably for extrapolations to higher-order systems.

The narrower A1 homogeneity range calculated in this work, as compared to assessments in references $^{[5,15,17-19]}$, is also due to a difference in preference of experimental data from Fountain and Forgeng ${ }^{[23]}$ over the data of van der Straten et al. ${ }^{[21]}$ and Takayama et al. ${ }^{[24]}$ as outlined in Section IIIA (see also Fig. 6).

The calculated thermodynamic properties of the intermetallic phases are summarized in Table V. $\Delta^{\mathrm{f}} \mathrm{H}_{298}$ values are also compared to the experimental data in Fig. 8. The calculated values are in good agreement with experiments with the exception of $\Delta^{\mathrm{f}} \mathrm{H}_{298}$ for the $\mathrm{L}_{2}$ phase. The difference between calculated and experimental values of more than $5 \mathrm{~kJ} / \mathrm{mol}$ could be attributed to the uncertainly of enthalpy determination by Balarin and Bartsch ${ }^{[26]}$ as discussed in Section IIIA.

The enthalpy of mixing of the liquid calculated at $1873 \mathrm{~K}$ is in excellent agreement with the calorimetric data from Wang et al. ${ }^{[30]}$ as shown in Fig. 9. Comparing different assessments of the liquid mixing properties, the enthalpy of mixing calculated from the present assessment agrees well with the calculations by Murray ${ }^{[5]}$, while the assessments ${ }^{[15,17-19]}$ give more negative effects of mixing. For comparison, relative differences between our and other assessments in $\Delta^{\text {mix }} \mathrm{H}$ values calculated for 50 at pct Ti at $1873 \mathrm{~K}$ were 9 pct, ${ }^{[17]} 15$ pct, ${ }^{[19]} 23$ pct, ${ }^{[18]}$ and 28 pct. ${ }^{[15]}$ 


\section{SUMMARY}

New experimental results and a new thermodynamic assessment of the phase equilibria and thermochemical data in the Co-Ti system were obtained:

1. The $\approx 220 \mathrm{~K}$ inconsistency in the literature data on the melting point of the $\mathrm{B} 2$ phase was resolved experimentally using two independent techniques: differential thermal analysis (DTA) and visual observation of melting (VOM). The maximum melting temperature was found to be $1776 \mathrm{~K} \pm 5 \mathrm{~K}$.

2. Two fundamentally different solidification paths for two Co-Ti alloys with 49.4 and 50.4 at pct Ti imply that the composition of the congruent melting point for the $\mathrm{B} 2$ phase lies between these two compositions and is thus close to equiatomic.

3. The newly obtained B2 melting temperature along with the critically evaluated phase diagram and thermochemical data from the literature were used to produce consistent thermodynamic description for the Co-Ti system. Two alternative models for the B2 phase, sublattice (SL) and modified sublattice (MSL), can be used interchangeably for the system description.

\section{ACKNOWLEDGMENTS}

The authors thank Prof. B. Sundman for helpful advice and discussion on B2 phase modeling using the MSL description. We also thank Dr. H. L. Lukas of the Max-Planck-Institut fuer Metallforschung, Stuttgart, Germany, for providing the software used in present assessment. 


\section{REFERENCES}

1. N. Saunders: Adv. Mater. and Processes, 1999, vol. 156 (3), pp. 29-31

2. K. Smardz, L. Smardz, and A. Jezierski: Acta Phys. Polonica A, 2000, vol. 97, pp. 50710.

3. M. Maaza, M. Spegel, C. Sella, B. Pardo, and A. Menelle, J. Corno, R. Gaziel: Sol. State Comm., 1999, vol. 112, pp. 177-81.

4. Y. Kwon and C. Lee: Mater. Sci. Eng. B, 1999, vol. 65, pp. 187-93.

5. J.L. Murray: Bull. Alloy Phase Diagrams: 1982, vol. 3, pp. 74-85; and J.L. Murray: Phase Diagrams of Binary Titanium Alloys, ASM International, Metals Park, OH, 1987, pp. 5968.

6. A. Iannucci, A.A, Johnson, E.J. Hughes, and P.W. Barton: J. Appl. Phys., 1968, vol. 39, pp. 2222-24.

7. H. Huthmann and G. Inden: Phys. Stat. Sol. A, 1975, vol. 28, pp. K129-30.

8. H. J. Wallbaum: Arch. Eisenhuettenw., 1941, vol. 10, pp. 521-26.

9. S.R. Butler, J.E. Hanlon, and R.J. Wasilewski: J. Phys. Chem. Sol., 1969, vol. 30, pp.28186.

10. I.I. Kornilov, E.V. Kachur, and O.K. Belousov: Metally, 1975, No. 2, pp. 209-10.

11. V.V. Pet'kov and M.V. Kireev: Metallofizika, 1971, vol. 33, pp. 107-15.

12. H.L. Lukas, E.-Th. Henig, and B. Zimmermann: CALPHAD, 1977, vol. 1, pp. 225-36.

13. B. Sundman, B. Jansson, and J. -O. Andersson: CALPHAD, 1985, vol. 9, pp. 153-90.

14. M. V. Nevitt: Trans. Am. Inst. Min. Eng., 1960, vol. 218, pp. 327-31.

15. L. Kaufman and H. Nesor, Metall. Trans. A, 1975, vol. 6, pp. 2115-22.

16. B. Uhrenius and K. Forsen: Metallkd., 1983, vol. 74, pp. 610-15. 
17. N. Saunders and A.P. Miodownik: CALPHAD: a comprehensive guide, Pergamon, Oxford, New-York, 1998, pp. 299-300.

18. P. Nash, H. Choo, and R.B. Schwarz: J. Mater. Sci., 1998, vol. 33, pp. 4929-36.

19. G. Cacciamani, R. Ferro, I. Ansara, and N. Dupin: Intermetallics, 2000, vol 8, pp. $213-$ 22; corrigendum in: Intermetallics, 2001, vol 9, p. 179.

20. Powder diffraction file ${ }^{\mathrm{TM}}$, International Centre for Diffraction Data, Newtown Square, PA, 1998, \# 17-0031.

21. P.J.M. van der Straten, G.F. Bastin, F.J.J. van Loo, and G.D. Rieck: Z. Metallkd., 1976, vol. 67 , pp. 152-57.

22. E.K. Zakharov and B.G. Livshitz: Izv. Akad. Nauk SSSR, OTN, 1962, No 5, pp. 143-50.

23. R.W. Fountain and W.D. Forgeng: Trans. Met. Soc. AIME, 1959, vol. 215, pp. 998-1008.

24. T. Takayama, M.Y. Wey, and T. Nishizawa: Trans. Jap. Inst. Met., 1981, vol. 22, pp. $315-25$.

25. J.-C. Zhao: Z. Metallkd., 1999, vol. 90, pp. 223-32.

26. M. Balarin and K. Bartsch: Z. Anorg. Allg. Chem., 1996, vol. 622, pp. 919-21.

27. A.K. Niessen, F.R. de Boer, R. Boom, P.F. de Châtel, and W.C.M. Mattens: CALPHAD, 1983, vol. 7, pp. 51-77.

28. V.G. Dubanov, A.Ya. Stomakhin, and A.F. Filippov: Izv. Vyssch. Uch. Zaved., 1975, No. 3, pp. 5-7.

29. Yu.O. Esin, M.G. Valishev, A.F. Ermakov, P.V. Gel'd, and M.S. Petrushevskii: Russ. J. Phys. Chem., 1981, vol. 55, pp. 417-18.

30. H. Wang, R. Lück, and B. Predel: Z. Metallkd., 1992, vol. 83, pp. 528-32.

31. Y. Ueda, T. Nishi, T. Oishi, and K. Ono: J. Jap. Inst. Met., 1986, vol. 50, pp. 1081-88.

32. A.T. Dinsdale: CALPHAD, 1991, vol. 15, pp. 317-425. 
33. A. Davydov, U.R. Kattner, B. Sundman, and K. Ozaki: XXVIII International CALPHAD Conference, Grenoble, France, 1999. Abstracts, p. 83.

34. O. Redlich and A.T. Kister: Ind. Eng. Chem., 1948,vol. 40, pp. 345-48.

35. M. Hillert and M. Jarl: CALPHAD, 1978, vol. 2, pp. 227-38.

36. G.R. Purdy and J.G. Parr: Trans. Met. Soc. AIME, 1960, vol. 218, pp. 225-27.

37. B. Sundman and J. Ågren: J. Phys. Chem. Solids, 1981, vol. 42, pp. 297-301.

38. I. Ansara, N. Dupin, H.-L. Lukas, and B. Sundman: J. Alloys and Comp., 1997, vol. 247, pp. 20-30.

39. V. H-.P. Stüwe and Y. Shimomura: Z. Metallkd., 1960, vol. 51, pp. 180-81.

40. T. Suzuki and K. Masumoto: Metall. Trans., 1972, vol. 3, pp. 2009-10.

41. N. Dupin and I. Ansara: Z. Metallkd., 1999, vol. 90, pp. 76-85.

42. I. Ansara, B. Sundman, and P. Willemin: Acta Metall., 1988, vol. 36, pp. 977-82.

43. F.R. de Boer, R. Boom, W.C.M. Mattens, A.R. Miedema, and A.K Niessen: in Cohesion in Metals, Transition Metal Alloys, North-Holland, Amsterdam, 1988, pp. 121, 261.

44. A.R. Miedema: Z. Metallkd., 1979, vol. 70, pp. 345-53.

45. N. Dupin and I. Ansara: J. Phase Equilibria, 1993, vol. 14, pp. 451-56.

46. N. Dupin: Ph. D. Thesis, Institut National Polytechnique de Grenoble, Grenoble, France, 1995.

47. N. Saunders, ThermoTech, Guildford, Surrey, UK: private communication, 1992; referenced in ${ }^{[46]}$.

48. F.L. Orrell and M.G. Fontana: Trans. Am. Soc. Met., 1955, vol. 47, pp. 554-64.

49. Y. Aoki: J. Phys. Soc. Jap., 1970, vol. 28, pp. 1451-56.

50. T. Nakamichi, Y. Aoki, and M. Yamamoto: J. Phys. Soc. Jap., 1970, vol. 28, pp. 590-95.

51. T. Nakamichi, Y. Aoki, and M. Yamamoto: J. Phys. Soc. Jap., 1968, vol. 25, pp. 77-81. 
52. B.A. Borok, E.K. Novikova, L.S, Golubeva, R.P. Schegoleva, and N.A. Ruch'eva: Metall. Term. Obr. Met., 1963, No. 2, pp. 94-98.

53. A.D. McQuillan: J. Inst. Met., 1951, vol. 80, pp. 363-68.

54. H. Kaneko and Y.C. Huang: J. Jap. Inst. Met., 1963, vol. 27, pp. 393-97.

55. W. Köster and E. Wagner: Z. Metallkd., 1937, vol. 29, pp. 230-32.

56. U. Haschimoto: Nippon Kinz. Gakk., 1938, vol.2, pp. 67-77.

57. J.C. Gachon and J. Hertz: CALPHAD, 1983, vol. 7, pp. 1-12.

58. P.A. Gomozov, Yu.V. Zasypalov, and B.M. Mogutnov: Russ. J. Phys. Chem., 1986, vol. 60, pp. $1122-24$.

59. Yu.V. Zasypalov, O.A. Kiselev, and B.M. Mogutnov: Zh. Fiz. Khim., 1986, vol. 60, pp. $158-61$.

60. Q. Guo and O.J. Kleppa: J. Alloys and Comp., 1998, vol. 269, pp. 181-86.

61. N.G. Krasheninnikova, B.M. Mogutnov, I.A. Tomilin, and N.G. Shaposhnikov: Russ. J. Phys. Chem., 1987, vol. 61, pp. 1627-30. 
Table I. Review of current assessments: list of models used and calculated B2 properties.

\begin{tabular}{|c|c|c|c|c|c|c|c|c|}
\hline \multirow{3}{*}{ Ref. } & \multicolumn{6}{|c|}{ Models: } & \multirow{3}{*}{$\begin{array}{c}\mathrm{T}_{\mathrm{m}}(\mathrm{B} 2) \\
(\mathrm{K})\end{array}$} & \multirow{3}{*}{$\begin{array}{c}\Delta^{\mathrm{f}} \mathrm{H}_{298}(\mathrm{~B} 2) \\
(\mathrm{kJ} / \mathrm{mol}- \\
\text { of-atoms })\end{array}$} \\
\hline & \multirow{2}{*}{$\begin{array}{l}\text { Liquid, A1, } \\
\text { A2, A3 }\end{array}$} & \multirow[b]{2}{*}{$\mathrm{L}_{2}$} & \multicolumn{2}{|c|}{ Laves } & \multirow[b]{2}{*}{ B2 } & \multirow[b]{2}{*}{$\mathrm{CoTi}_{2}$} & & \\
\hline & & & C36 & $\mathrm{C} 15$ & & & & \\
\hline [5] & DS & SL & $\mathrm{LC}$ & $\mathrm{LC}$ & SL & $\mathrm{LC}$ & 1598 & -33.3 \\
\hline$[15]$ & DS & $\mathrm{LC}$ & - & $\mathrm{LC}$ & $\mathrm{LC}$ & $\mathrm{LC}$ & 1796 & -42.2 \\
\hline [16] & DS & SL & - & $\mathrm{LC}$ & - & - & - & - \\
\hline [17] & DS & SL & SL & SL & SL & $\mathrm{LC}$ & 1709 & - \\
\hline$[18]$ & DS & $\mathrm{LC}$ & - & $\mathrm{LC}$ & $\mathrm{LC}$ & $\mathrm{LC}$ & 1700 & -40.5 \\
\hline [19] & DS & MSL & SL & SL & MSL & LC & 1728 & -40.9 \\
\hline $\begin{array}{l}\text { this } \\
\text { work }\end{array}$ & DS & MSL & SL & SL & SL, MSL & $\mathrm{LC}$ & 1774 & -42.2 \\
\hline
\end{tabular}

Models: DS- disordered solution; LC - line compound; SL - sublattice; MSL - modified sublattice (order-disorder). 
Table II. Co-Ti alloy measured temperatures from DTA and VOM with summary of liquidus $\left(\mathrm{T}_{\mathrm{L}}\right)$ and solidus $\left(\mathrm{T}_{\mathrm{S}}\right)$ values (in $\left.\mathrm{K}\right)$.

\begin{tabular}{|c|c|c|c|c|c|c|c|c|c|}
\hline \multirow{3}{*}{ \# } & \multirow{3}{*}{$\begin{array}{l}\text { at pct Ti } \\
(\sigma)\end{array}$} & \multicolumn{6}{|c|}{ DTA } & \multirow{2}{*}{\multicolumn{2}{|c|}{ VOM }} \\
\hline & & \multicolumn{2}{|c|}{ Heating } & \multicolumn{2}{|c|}{ Cooling } & \multicolumn{2}{|c|}{ Summary } & & \\
\hline & & $\mathrm{T}_{\text {onset }}$ & $T_{\text {peak }}$ & $\mathrm{T}_{\text {onset }}$ & $\mathrm{T}_{\text {peak }}$ & $\mathrm{T}_{\mathrm{L}}$ & $\mathrm{T}_{\mathrm{S}}$ & $\mathrm{T}_{\text {first melt }}$ & $\mathrm{T}_{\text {collapse }}$ \\
\hline I & $\begin{array}{l}48.1 \\
(0.6)\end{array}$ & 1733 & 1774 & 1758 & 1731 & $\begin{array}{c}1758-1774 \\
1774 *\end{array}$ & $1731-1733$ & 1733 & 1753 \\
\hline II & $\begin{array}{l}49.4 \\
(0.6)\end{array}$ & 1739 & 1775 & 1761 & 1739 & $\begin{array}{c}1761-1775 \\
1775^{*}\end{array}$ & 1739 & 1733 & 1753 \\
\hline III & $\begin{array}{l}50.4 \\
(0.4)\end{array}$ & 1741 & 1776 & 1763 & 1739 & $\begin{array}{c}1763-1776 \\
1776^{*}\end{array}$ & $1739-1741$ & 1733 & 1753 \\
\hline
\end{tabular}

* Values used for the optimization 
Table III. Summary of thermochemical and phase diagram experimental data.

\begin{tabular}{|c|c|c|c|c|c|}
\hline Type of experimental data & Method & $\begin{array}{c}\text { At pct } \\
\text { Ti }\end{array}$ & $\mathrm{T}$ range $(\mathrm{K})$ & Ref. & $\begin{array}{l}\text { Data } \\
\text { used }\end{array}$ \\
\hline $\mathrm{T}_{\mathrm{m}}(\mathrm{B} 2)$ and solvus (B2) & $\mathrm{XD}, \mathrm{TA}$ & $45-53$ & $650-1600$ & [6] & Yes* \\
\hline $\mathrm{T}_{\mathrm{m}}(\mathrm{B} 2)$ & ND & 48 & $300-1650$ & {$[7]$} & No \\
\hline $\mathrm{T}_{\mathrm{m}}(\mathrm{B} 2)$ & TA & 50 & 1773 & [9] & Yes \\
\hline $\mathrm{T}_{\mathrm{m}}(\mathrm{B} 2)$ & TA & 50 & $1450-1800$ & [10] & Yes \\
\hline $\begin{array}{l}\text { Liquidus, solidus (A1, C36, } \\
\text { C15, B2), nonvariants }\end{array}$ & TA & $0-53$ & $1400-1800$ & {$[8]$} & Yes* \\
\hline $\begin{array}{l}\text { Solidus, liquidus, solvus (all } \\
\text { but A2), nonvariants }\end{array}$ & $\mathrm{MH}, \mathrm{TA}, \mathrm{XD}$ & $0-100$ & $950-1800$ & [11] & Yes* \\
\hline Liquidus, solidus (A1) & TA, MP & $10-25$ & $1450-1650$ & [16] & Yes \\
\hline $\begin{array}{l}\text { Liquidus, solidus, solvus } \\
\left(\mathrm{A} 1, \mathrm{~L} 1_{2}, \mathrm{C} 36\right), \mathrm{T}_{\mathrm{c}}(\mathrm{A} 1)\end{array}$ & $\begin{array}{c}\text { MG, TA, MH, MT, } \\
\text { XD }\end{array}$ & $0-45$ & $450-1800$ & [22] & Yes* \\
\hline Solvus (all phases) & MP, MT, XD & $0-100$ & $950-1450$ & [21] & Yes* \\
\hline $\begin{array}{l}\left.\text { Solvus (A1, } \mathrm{L} 1_{2}\right) \\
\text { nonvariants }\end{array}$ & CA, MH, MT, XD & $0-25$ & $750-1500$ & [23] & Yes \\
\hline Solvus (A1, L1 2 ) & MP, XD & $0-20$ & $850-1400$ & [24] & Yes \\
\hline Solvus $\left(\mathrm{CoTi}_{2}\right)$ & MT, XD & $66-68$ & $900-1300$ & [36] & Yes* \\
\hline Solvus (B2) & XD & $40-55$ & 1273 & [39] & Yes \\
\hline $\begin{array}{l}\left.\text { Solvus (B2, } \mathrm{CoTi}_{2}, \mathrm{~A} 2\right) \text {, } \\
\text { nonvariants }\end{array}$ & MT, TA, XD & $50-100$ & $950-1350$ & [48] & Yes \\
\hline Solvus $\left(\mathrm{L1}_{2}\right)$ & $\mathrm{XD}$ & $20-25$ & 1273 & [49] & Yes \\
\hline Solvus (C36) & $\mathrm{XD}$ & $28-31$ & 1273 & [50] & Yes \\
\hline Solvus (C15) & $\mathrm{XD}$ & $32-34$ & 1273 & [51] & Yes \\
\hline Solvus (A2) & $\mathrm{DL}, \mathrm{MH}, \mathrm{MT}, \mathrm{XD}$ & $90-98$ & $1000-1250$ & [52] & No \\
\hline Solvus (A2) & IM & $95-100$ & $1000-1150$ & [53] & Yes \\
\hline Solvus (A2, hcp), eutectoid & EM & $93-100$ & $950-1150$ & [54] & Yes \\
\hline $\mathrm{T}_{\mathrm{c}}(\mathrm{A} 1)$ & MG & $0-10$ & $1150-1400$ & [55] & Yes \\
\hline $\mathrm{T}_{\mathrm{c}}(\mathrm{A} 1)$ & MG & $0-10$ & $1150-1400$ & [56] & Yes \\
\hline$\Delta^{\mathrm{f}} \mathrm{H}\left(\mathrm{L1}_{2}\right)$ & IM & 25 & 1300 & [26] & Yes \\
\hline$\Delta^{\mathrm{mix}} \mathrm{H}$ (liquid) & CL & $0-5$ & 1823 & [28] & Yes \\
\hline$\Delta^{\mathrm{mix}} \mathrm{H}$ (liquid) & CL & $0-50$ & 2000 & [29] & Yes \\
\hline$\Delta^{\operatorname{mix}} \mathrm{H}$ (liquid) & MS & $0-90$ & $1850-2020$ & [31] & No \\
\hline$\Delta^{\mathrm{mix}} \mathrm{H}$ (liquid) & CL & $0-40$ & 1873 & [30] & Yes \\
\hline$\Delta^{\mathrm{f}} \mathrm{H}(\mathrm{B} 2, \mathrm{C} 36)$ & CL & 33,50 & 1432,1490 & {$[57]$} & Yes \\
\hline$\Delta^{\mathrm{f}} \mathrm{H}(\mathrm{B} 2)$ & CL & 50 & 1030 & [58] & Yes \\
\hline$\Delta^{\mathrm{f}} \mathrm{H}(\mathrm{B} 2)$ & CL & 50 & 1067 & [59] & Yes \\
\hline$\Delta^{\mathrm{f}} \mathrm{H}(\mathrm{B} 2)$ & $\mathrm{CL}$ & 50 & 1477 & [60] & Yes \\
\hline $\mathrm{C}_{\mathrm{p}}(\mathrm{B} 2)$ & $\mathrm{CL}$ & 50 & $50-300$ & [61] & Yes \\
\hline $\mathrm{T}_{\mathrm{m}}(\mathrm{B} 2)$ & TA, VO, XD, MP & $48-51$ & $1600-1800$ & this work & Yes \\
\hline
\end{tabular}


Table IV. Models Description

\begin{tabular}{|c|c|c|c|c|}
\hline Phase & Model (Eq. [\#]) & Parameter & $\mathrm{a}_{\mathrm{i}}$ & $b_{i}$ \\
\hline Liquid & $\begin{array}{c}\text { Disordered solution }(\mathrm{Co}, \mathrm{Ti}) \\
(\text { Eqs }[2-5])\end{array}$ & $\begin{array}{l}{ }^{0} \mathrm{~L}_{\mathrm{Co}, \mathrm{Ti}} \\
{ }^{1} \mathrm{~L}_{\mathrm{Co}} \mathrm{Ti}\end{array}$ & $\begin{array}{l}-119780 \\
-2163\end{array}$ & 15.06 \\
\hline A1 & $\begin{array}{c}\text { Disordered solution }(\mathrm{Co}, \mathrm{Ti}) \\
\text { (Eqs [2-12]) }\end{array}$ & $\begin{array}{c}{ }^{0} \mathrm{~L}_{\mathrm{Co}, \mathrm{Ti}} \\
{ }^{1} \mathrm{~L}_{\mathrm{Co}, \mathrm{Ti}} \\
\mathrm{T}_{\mathrm{Co}, \mathrm{Ti}}, \beta_{\mathrm{Co}, \mathrm{Ti}}\end{array}$ & $\begin{array}{l}-77800 \\
-1300 \\
-1400\end{array}$ & -7.4 \\
\hline A2 & $\begin{array}{c}\text { Disordered solution }(\mathrm{Co}, \mathrm{Ti}, \mathrm{Va}) \\
(\text { Eqs }[2-12])\end{array}$ & $\begin{array}{c}{ }^{0} \mathrm{~L}_{\mathrm{Co}, \mathrm{Ti}} \\
{ }^{0} \mathrm{~L}_{\mathrm{Co}, \mathrm{Va}} \\
{ }^{0} \mathrm{~L}_{\mathrm{Ti}, \mathrm{Va}} \\
\mathrm{T}_{\mathrm{Co}, \mathrm{Ti}}, \beta_{\mathrm{Co}, \mathrm{Ti}}\end{array}$ & $\begin{array}{c}-92966 \\
135000^{\mathrm{s}} \\
150000^{\mathrm{s}} \\
-1400^{4} \\
\end{array}$ & 12.38 \\
\hline A3 & $\begin{array}{l}\text { Disordered solution }(\mathrm{Co}, \mathrm{Ti}) \\
(\text { Eqs }[2-12])\end{array}$ & $\begin{array}{c}{ }^{0} \mathrm{~L}_{\mathrm{Co}, \mathrm{Ti}} \\
\mathrm{T}_{\mathrm{Co}, \mathrm{Ti}}, \beta_{\mathrm{Co}, \mathrm{Ti}}\end{array}$ & $\begin{array}{l}-60033 \\
-1400\end{array}$ & 0 \\
\hline $\mathrm{L}_{2}$ & $\begin{array}{c}\operatorname{MSL}(\mathrm{Co}, \mathrm{Ti})_{0.75}(\mathrm{Ti}, \mathrm{Co})_{0.25} \\
\text { (Eq. [20]) }\end{array}$ & $\begin{aligned} \mathrm{G}_{\mathrm{Co}: \mathrm{Ti}} & =\mathrm{G}_{\mathrm{Ti}: \mathrm{Co}} \\
{ }^{0} \mathrm{~L}_{\mathrm{Co}, \mathrm{Ti}: \mathrm{Co}} & ={ }^{0} \mathrm{~L}_{\mathrm{Co}, \mathrm{Ti}} \mathrm{Ti} \\
{ }^{1} \mathrm{~L}_{\mathrm{Co}, \mathrm{Ti}: \mathrm{Co}} & ={ }^{1} \mathrm{~L}_{\mathrm{C}, \mathrm{Ti}: \mathrm{Ti}} \\
{ }^{1} \mathrm{~L}_{\mathrm{Co} \mathrm{C}, \mathrm{Ti}} & ={ }^{1} \mathrm{~L}_{\mathrm{T}: \mathrm{Co}, \mathrm{Ti}} \\
\mathrm{T}_{\mathrm{Co}: \mathrm{Ti}} & =\mathrm{T}_{\mathrm{Ti}: \mathrm{Co}} \\
\mathrm{T}_{\mathrm{Co}, \mathrm{Ti}: \mathrm{Co}} & =\mathrm{T}_{\mathrm{Co}, \mathrm{Ti}: \mathrm{Ti}}\end{aligned}$ & $\begin{array}{c}-58800 \\
-117600 \\
-3000 \\
-1000 \\
-3140 \\
-6280\end{array}$ & $\begin{array}{c}20.4 \\
40.8 \\
1.8 \\
0.6\end{array}$ \\
\hline $\mathrm{C} 15$ & $\begin{array}{l}\mathrm{SL}(\mathrm{Co}, \mathrm{Ti})_{2}(\mathrm{Ti}, \mathrm{Co}) \\
\quad(\mathrm{Eqs}[14-15])\end{array}$ & $\begin{array}{c}\Delta^{\mathrm{f}} \mathrm{G}_{\mathrm{Co}: \mathrm{Co}}=\Delta^{\mathrm{f}} \mathrm{G}_{\mathrm{Ti}} \mathrm{Ti} \\
\Delta^{\mathrm{f}} \mathrm{G}_{\mathrm{Co}: \mathrm{Ti}} \\
\Delta^{\mathrm{f}} \mathrm{G}_{\mathrm{Ti}: \mathrm{Co}}\end{array}$ & $\begin{array}{r}15000^{\mathrm{s}} \\
-101700 \\
131700 \\
\end{array}$ & $\begin{array}{r}11.07 \\
-11.07\end{array}$ \\
\hline $\mathrm{C} 36$ & $\begin{array}{l}\mathrm{SL}(\mathrm{Co}, \mathrm{Ti})_{2}(\mathrm{Ti}, \mathrm{Co}) \\
\quad(\mathrm{Eqs}[14-15])\end{array}$ & $\begin{array}{c}\Delta^{\mathrm{f}} \mathrm{G}_{\mathrm{Co}: \mathrm{Co}}=\Delta^{\mathrm{f}} \mathrm{G}_{\mathrm{Ti}} \mathrm{Ti} \\
\Delta^{\mathrm{f}} \mathrm{G}_{\mathrm{Co}: \mathrm{Ti}} \\
\Delta^{\mathrm{f}} \mathrm{G}_{\mathrm{Ti}} \mathrm{Co} \\
{ }^{0} \mathrm{~L}_{\mathrm{Co}: \mathrm{Co}, \mathrm{Ti}}={ }^{\circ} \mathrm{L}_{\mathrm{Ti}: \mathrm{Co}, \mathrm{Ti}}\end{array}$ & $\begin{array}{c}15000^{\mathrm{s}} \\
-101700 \\
131700 \\
-34000\end{array}$ & $\begin{array}{c}11.38 \\
-11.38 \\
17.4\end{array}$ \\
\hline \multirow[t]{2}{*}{ B2 } & $\begin{array}{l}\mathrm{SL}(\mathrm{Co}, \mathrm{Va})(\mathrm{Ti}, \mathrm{Co}) \\
\quad(\mathrm{Eqs}[16-17])\end{array}$ & 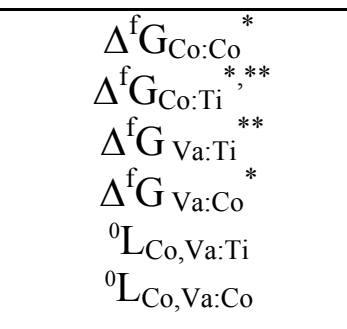 & $\begin{array}{c}0 \\
-102209 \\
60000^{\mathrm{s}} \\
148500^{\mathrm{s}} \\
-57360 \\
45030^{\mathrm{s}}\end{array}$ & $\begin{array}{r}19.42 \\
-35.62 \\
9.66 \\
-34.47\end{array}$ \\
\hline & $\begin{array}{c}\operatorname{MSL}(\mathrm{Co}, \mathrm{Ti}, \mathrm{Va})_{0.5}(\mathrm{Ti}, \mathrm{Co}, \mathrm{Va})_{0.5} \\
(\mathrm{Eq}[19])\end{array}$ & $\begin{aligned} \mathrm{G}_{\mathrm{Co}: \mathrm{Ti}} & =\mathrm{G}_{\mathrm{Ti}: \mathrm{Co}} \\
\mathrm{G}_{\mathrm{Co}: \mathrm{Va}} & =\mathrm{G}_{\mathrm{Va}: \mathrm{Co}} \\
\mathrm{G}_{\mathrm{Ti}: \mathrm{Va}} & =\mathrm{G}_{\mathrm{Va}: \mathrm{Ti}} \\
{ }^{0} \mathrm{~L}_{\mathrm{Co}, \mathrm{Ti}: \mathrm{Co}} & ={ }^{0} \mathrm{~L}_{\mathrm{Co}: \mathrm{Co}, \mathrm{Ti}} \\
{ }^{1} \mathrm{~L}_{\mathrm{Co}, \mathrm{Ti}: \mathrm{Co}} & ={ }^{1} \mathrm{~L}_{\mathrm{Co}: \mathrm{Co}, \mathrm{Ti}} \\
{ }^{0} \mathrm{~L}_{\mathrm{Co}, \mathrm{Ti}: \mathrm{Ti}} & ={ }^{0} \mathrm{~L}_{\mathrm{Ti}: \mathrm{Co}, \mathrm{Ti}} \\
\mathrm{T}_{\mathrm{Co}: \mathrm{Ti}} & =\mathrm{T}_{\mathrm{Ti}: \mathrm{Co}}\end{aligned}$ & $\begin{array}{c}-53950 \\
67500^{\mathrm{s}} \\
75000^{\mathrm{s}} \\
-33118 \\
-11630 \\
40388 \\
-500 \\
\end{array}$ & 14.03 \\
\hline $\mathrm{CoTi}_{2}$ & ine compound $\mathrm{Co}_{0.33} \mathrm{Ti}_{0.67}$ (Eq. [13]) & $\Delta^{\mathrm{f}} \mathrm{G}$ & -36604 & 7.05 \\
\hline
\end{tabular}

Notes: 1) $a_{i}$ and $b_{i}$ coefficients for the $G$ and $L$ parameters are given in $J / m o l$ and $J / m o l K$, respectively; $T_{c}$ in $K$, and $\beta$ in Bohr magnetons; 2$)^{*}$ - relative to ${ }^{\circ} \mathrm{G}_{\mathrm{Ti}}^{\mathrm{A} 2}\left[{ }^{[32]} ;{ }^{* *}\right.$ - relative to ${ }^{\circ} \mathrm{G}_{\mathrm{Co}}^{\mathrm{A} 2}{ }^{[32]}$ (no superscript symbol ${ }^{(*)}$ in the $\Delta^{\mathrm{f}} \mathrm{G}_{\mathrm{i}: \mathrm{j}}$ means that $\mathrm{A} 3(\mathrm{Ti})$ and $\mathrm{A} 3(\mathrm{Co})$ were used as references); ${ }^{\mathrm{s}}$ - pre-selected (fixed) values. 
Table V. Calculated Thermodynamic Properties of the Intermetallic Compounds

\begin{tabular}{cccc}
\hline Phase & $\begin{array}{c}\text { composition } \\
\text { (at pct Ti) }\end{array}$ & $\begin{array}{c}\Delta^{\mathrm{f}} \mathrm{H}_{298} \\
(\mathrm{~J} / \text { mol-of-atoms })\end{array}$ & $\begin{array}{c}\Delta^{\mathrm{f}} \mathrm{S}_{298} \\
(\mathrm{~J} / \text { mol-of-atoms })\end{array}$ \\
\hline $\mathrm{L} 1_{2}$ & 24 & -20823 & 2.3 \\
$\mathrm{C} 36$ & 31 & -27246 & 1.3 \\
$\mathrm{C} 15$ & 33 & -28219 & 1.0 \\
$\mathrm{~B} 2$ & 50 & -42177 & -2.6 \\
$\mathrm{CoTi}_{2}$ & 67 & -33763 & -4.7 \\
\hline
\end{tabular}

Table VI. Invariant equilibria calculated in the present work and compared to the evaluation by Murray ${ }^{[5]}$

\begin{tabular}{|c|c|c|c|c|c|c|c|c|}
\hline \multirow{2}{*}{ Equilibria } & \multicolumn{4}{|c|}{ Present assessment } & \multicolumn{4}{|c|}{$[5]$} \\
\hline & $\mathrm{x}_{1}$ & $\mathrm{x}_{2}$ & $\mathrm{x}_{3}$ & $\mathrm{~T}(\mathrm{~K})$ & $\mathrm{x}_{1}$ & $\mathrm{x}_{2}$ & $\mathrm{x}_{3}$ & $\mathrm{~T}(\mathrm{~K})$ \\
\hline $\mathrm{A} 2=\mathrm{A} 3+\mathrm{CoTi}_{2}$ & 93.0 & 98.1 & 66.7 & 959 & 93.0 & 99.1 & 66.8 & 958 \\
\hline liquid $=\mathrm{A} 2+\mathrm{CoTi}_{2}$ & 78.7 & 85.5 & 66.7 & 1293 & 76.8 & 85.5 & 66.9 & 1293 \\
\hline \multirow{2}{*}{ liquid $+\mathrm{B} 2=\mathrm{CoTi}_{2}$} & $76.2^{*}$ & $52.3^{*}$ & $66.7^{*}$ & $1333^{*}$ & \multirow{2}{*}{72.9} & \multirow{2}{*}{51} & \multirow{2}{*}{66.9} & \multirow{2}{*}{1331} \\
\hline & $76.4^{* *}$ & $52.2^{* *}$ & $66.7^{* *}$ & $1330^{* *}$ & & & & \\
\hline \multirow{2}{*}{ liquid $=\mathrm{B} 2$} & $49.8^{*}$ & $49.8^{*}$ & - & $1773^{*}$ & \multirow{2}{*}{50} & \multirow{2}{*}{50} & \multirow{2}{*}{ - } & \multirow{2}{*}{1598} \\
\hline & $50.2^{* *}$ & $50.2^{* *}$ & - & $1774^{* *}$ & & & & \\
\hline \multirow{2}{*}{$\mathrm{B} 2+$ liquid $=\mathrm{C} 15$} & $43.0^{*}$ & $28.5^{*}$ & $32.6^{*}$ & $1509^{*}$ & \multirow{2}{*}{44.8} & \multirow{2}{*}{32.8} & \multirow{2}{*}{33.5} & \multirow{2}{*}{1508} \\
\hline & $44.0^{* *}$ & $29.3^{* *}$ & $32.7^{* *}$ & $1515^{* *}$ & & & & \\
\hline $\mathrm{C} 15+$ liquid $=\mathrm{C} 36$ & 32.0 & 25.2 & 30.9 & 1475 & 33 & 29 & 31.3 & 1483 \\
\hline $\mathrm{C} 36+$ liquid $=\mathrm{L1}_{2}$ & 30.3 & 23.9 & 24.2 & 1459 & 28 & 22.8 & 24.2 & 1443 \\
\hline liquid $=\mathrm{L} 1_{2}$ & 20.3 & 20.3 & - & 1454 & - & - & - & - \\
\hline liquid $+\mathrm{A} 1=\mathrm{L1}_{2}$ & 20.2 & 15.4 & 20.0 & 1455 & 20.7 & 14.1 & 19.3 & 1483 \\
\hline $\mathrm{A} 1=\mathrm{L1}_{2}+\mathrm{A} 3$ & 0.6 & 25.0 & 0.02 & 640 & - & - & - & - \\
\hline
\end{tabular}

*,** - calculated using B2 MSL and SL models, respectively 


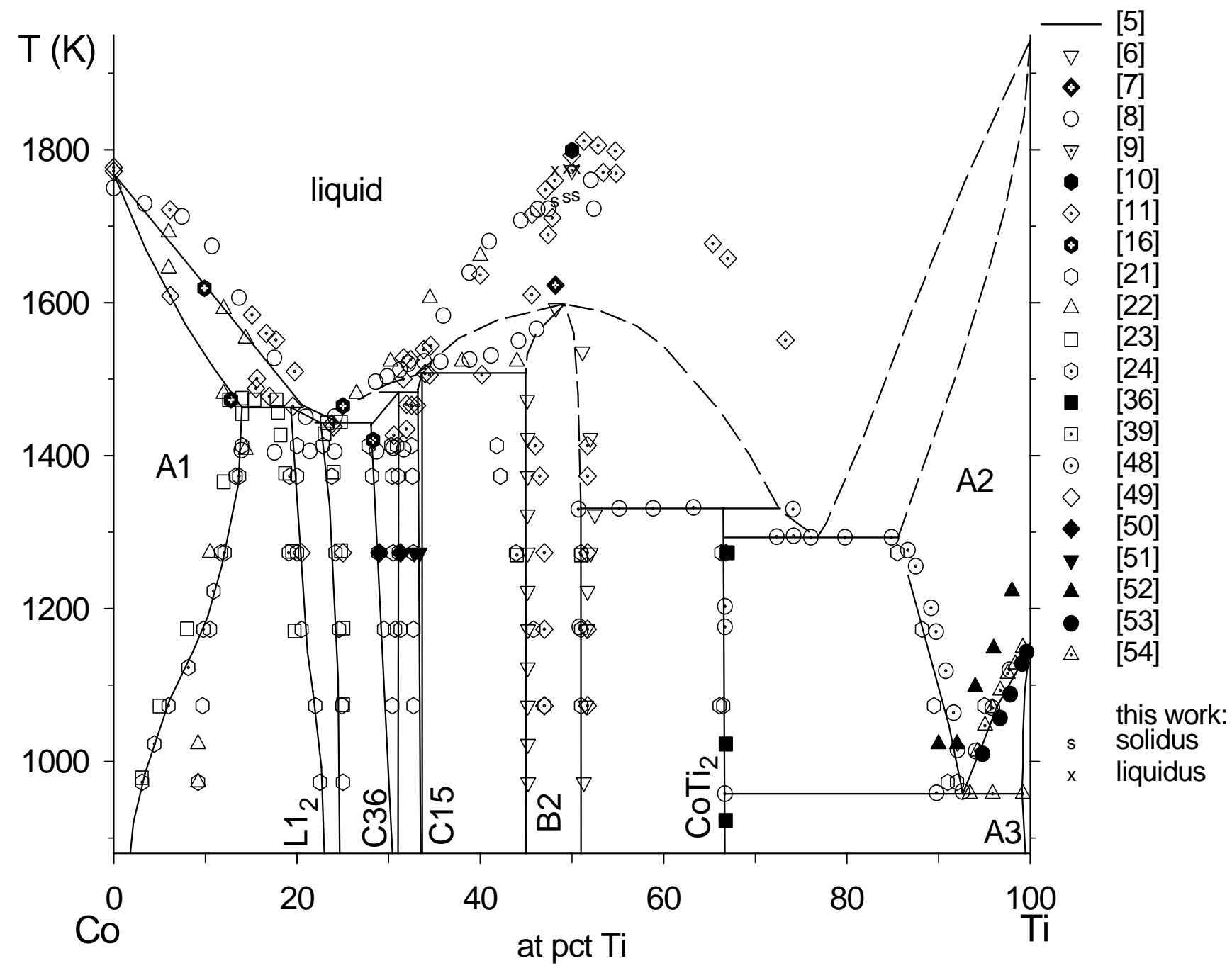

Fig. 1. All experimental data (symbols) compared to the Co-Ti phase diagram evaluated by Murray ${ }^{[5]}$ (solid and dashed lines). 


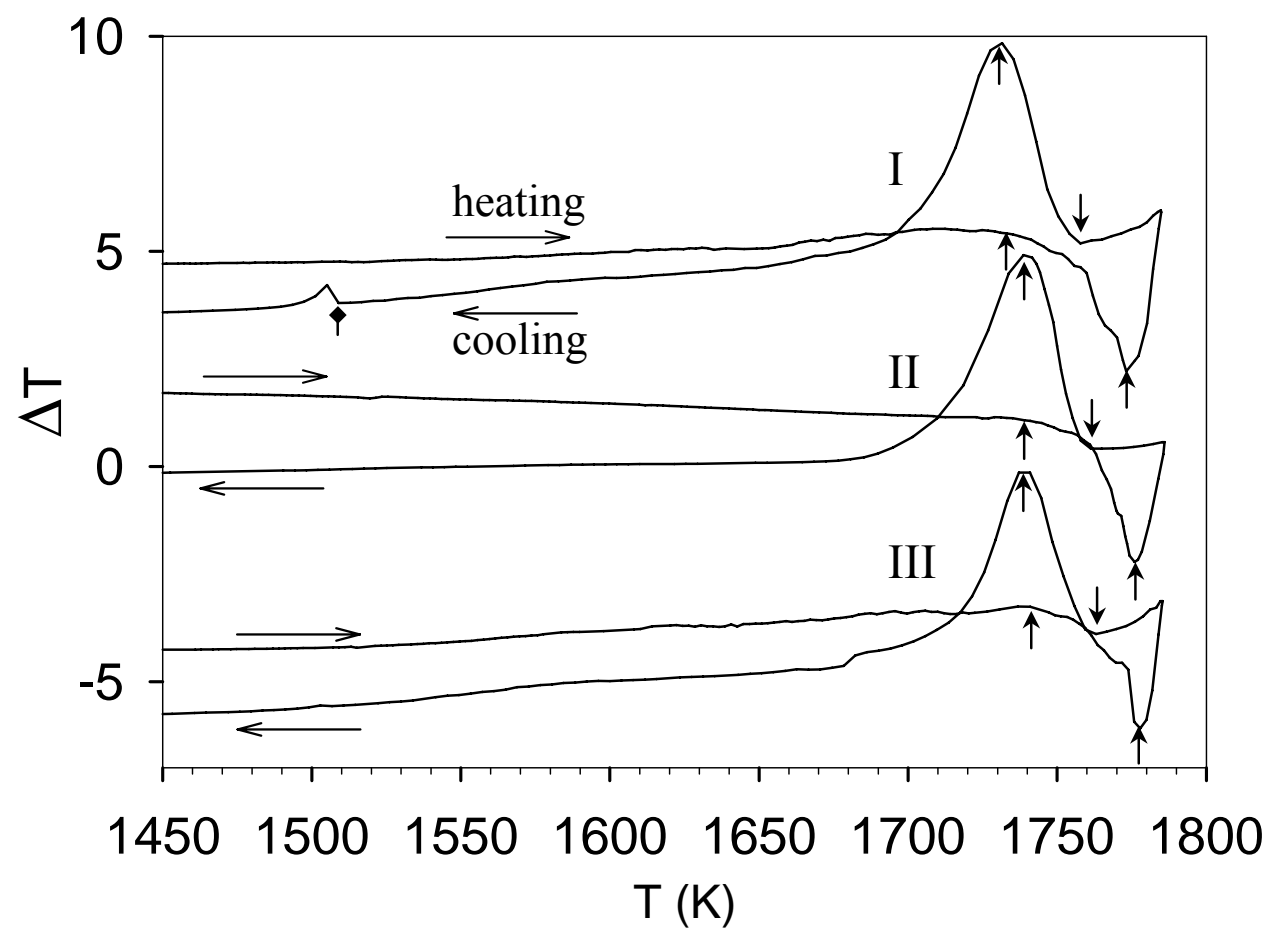

Fig 2. DTA curves of the Co-Ti alloys: I (48.1 at pct Ti); II (49.4 at pct Ti), III (50.4 at pct Ti). Horizontal arrows identify heating and cooling curves. Vertical arrows indicate solidus and liquidus thermal arrests; vertical diamond arrow (sample I, cooling curve) identifies peritectic reaction: $\mathrm{B} 2+$ liquid $\rightarrow \mathrm{C} 15$. 


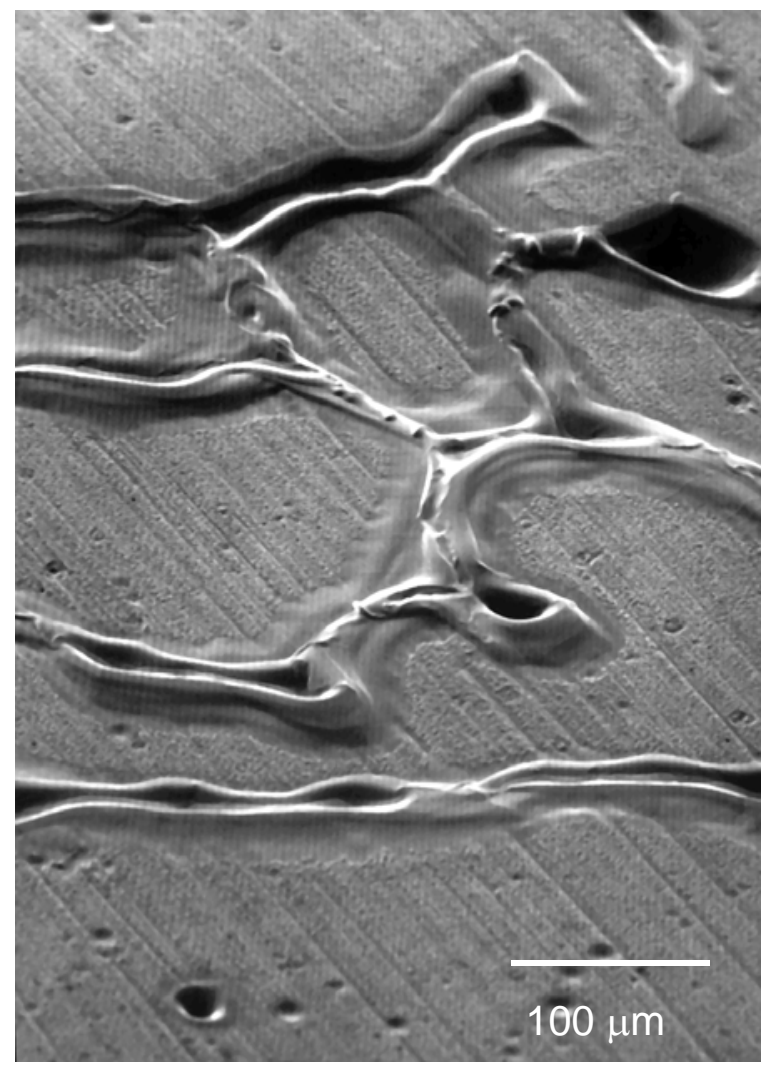

Fig 3. SEM image of sample I equilibrated at $1733 \mathrm{~K}$ : partial melting at the grain boundaries is clearly visible (note scratches from polishing on the intact surface) 


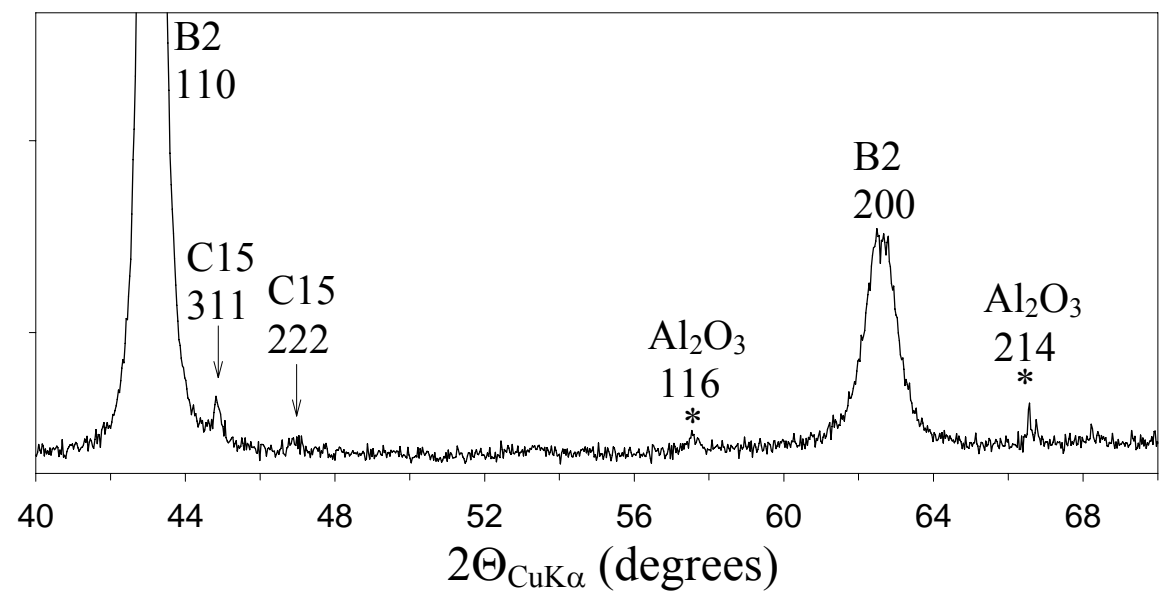

Fig 4. XRD pattern of sample I after the DTA run: arrows indicate presence of the C15 phase; * - residual alumina reflections (from the crucible material). 

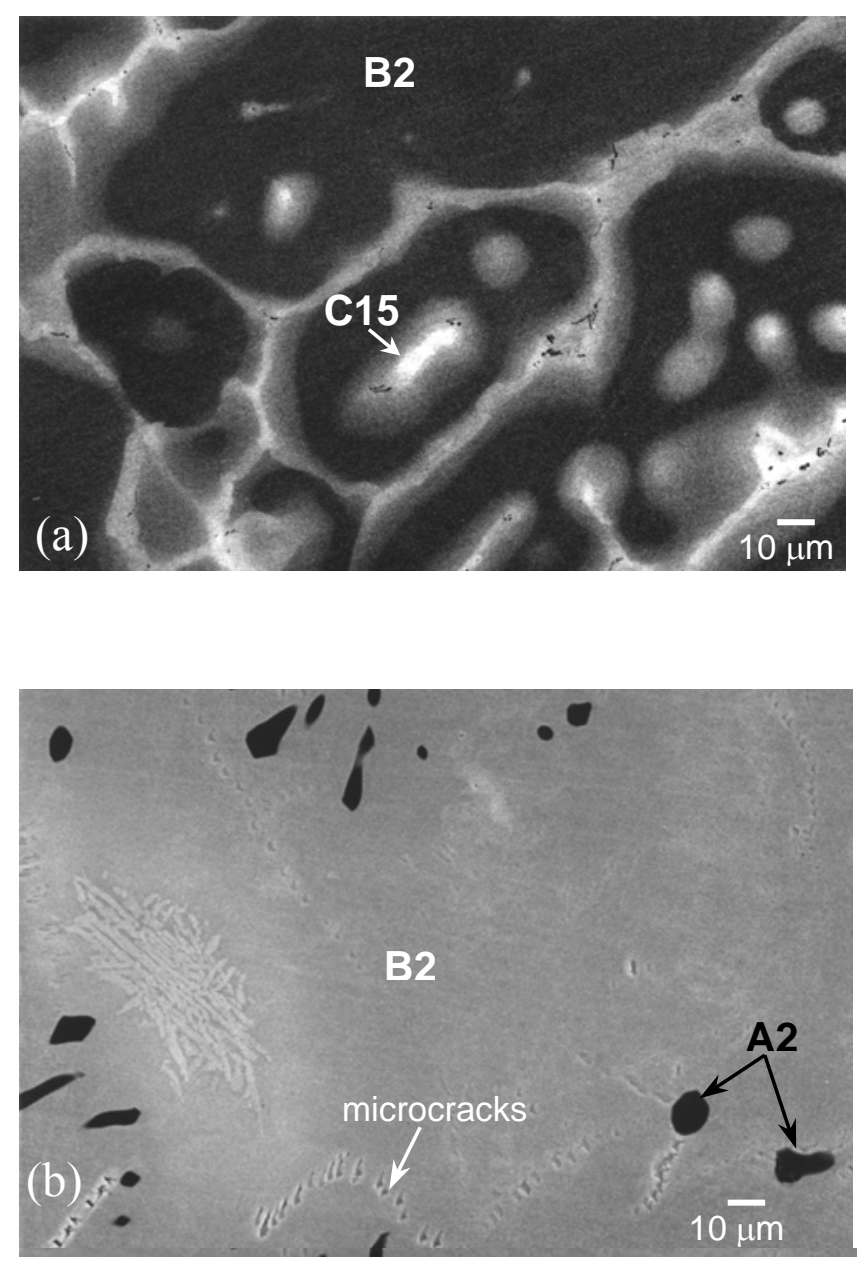

Fig 5. Cross-sectional back-scattered SEM microphotographs of:

(a) sample II solidified from $1753 \mathrm{~K}$ : dark matrix is B2 phase (49.5 to 49.8 at pct Ti); lighter areas at the grain boundaries are enriched with cobalt (34 to $42 \% \mathrm{Ti}$ ); bright particles - Laves (C15) phase;

(b) sample III solidified from $1783 \mathrm{~K}$ : light-gray to gray matrix is B2 phase (49.6 to 49.9 at pct Ti); dark particles are Ti-rich A2 solid solutions with 89 to 94 at pct Ti. 


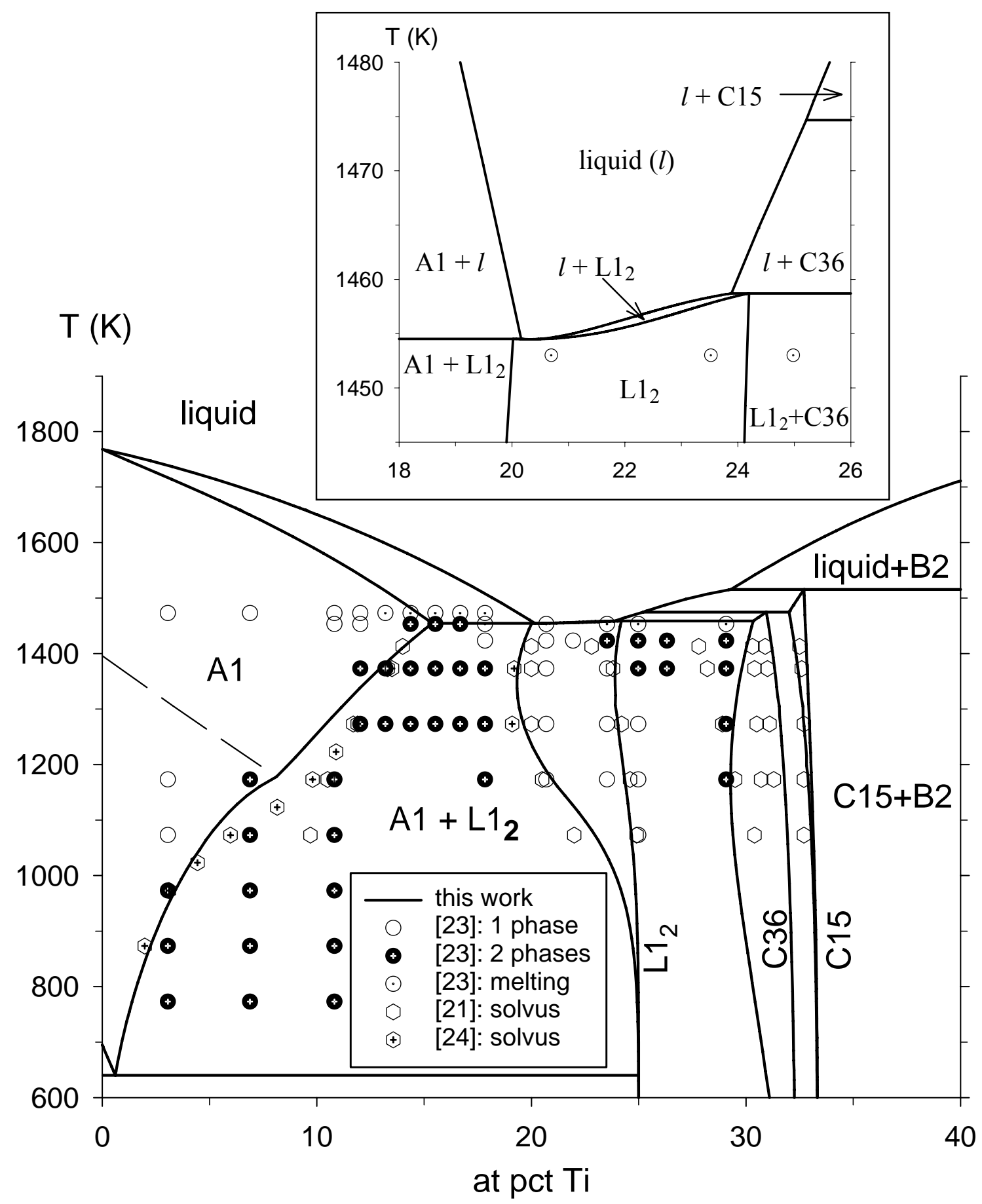

Fig. 6. Selected solvus data in the Co-rich corner of the phase diagram as compared to the present assessment (insert shows detailed equilibria involving $\mathrm{L}_{2}$ and liquid phases). 


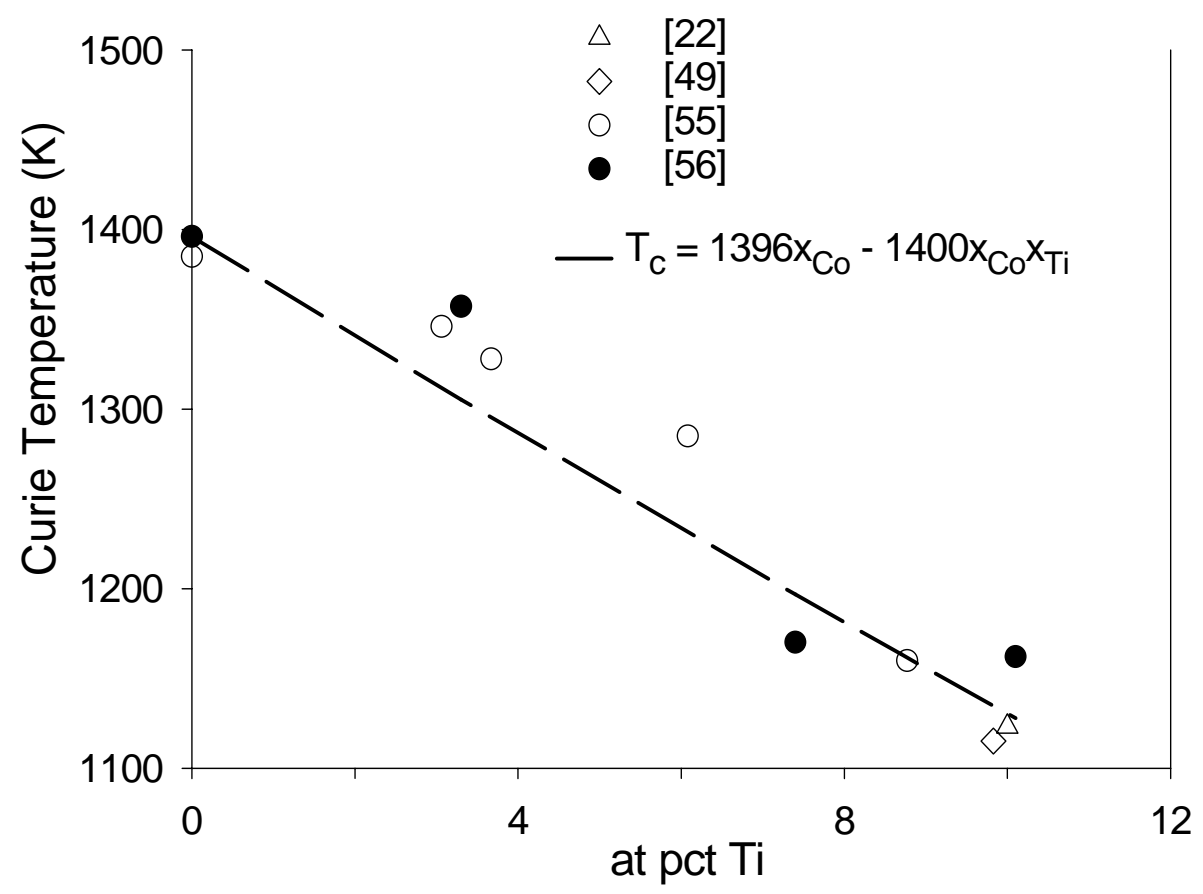

Fig. 7. Experimental and calculated Curie temperature $\left(T_{c}\right)$ for the A1 phase 


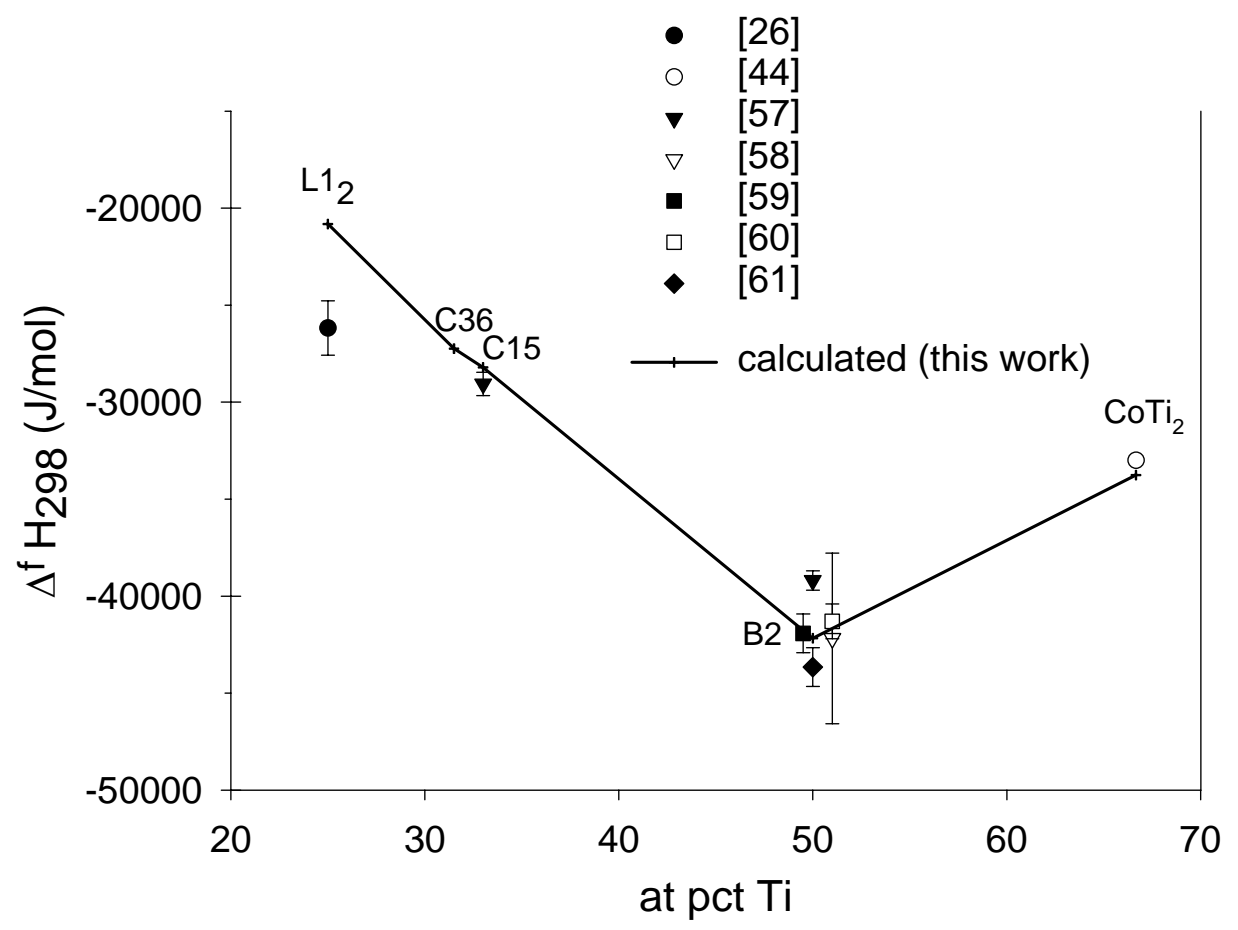

Fig. 8. Experimental and calculated enthalpy of formation of intermetallics at $298 \mathrm{~K}$. 


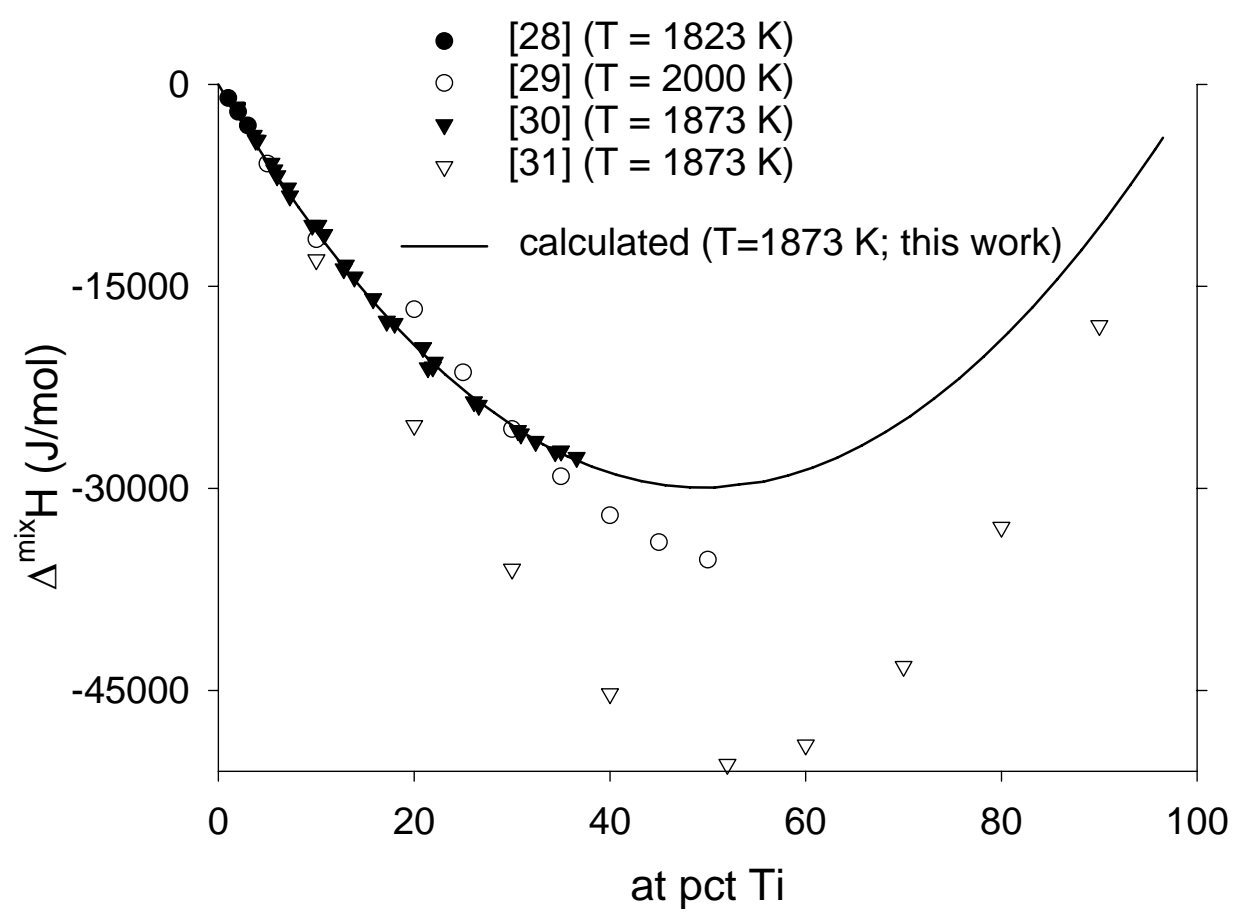

Fig. 9. Experimental and calculated $\Delta^{\mathrm{mix}} \mathrm{H}$ in the liquid. 


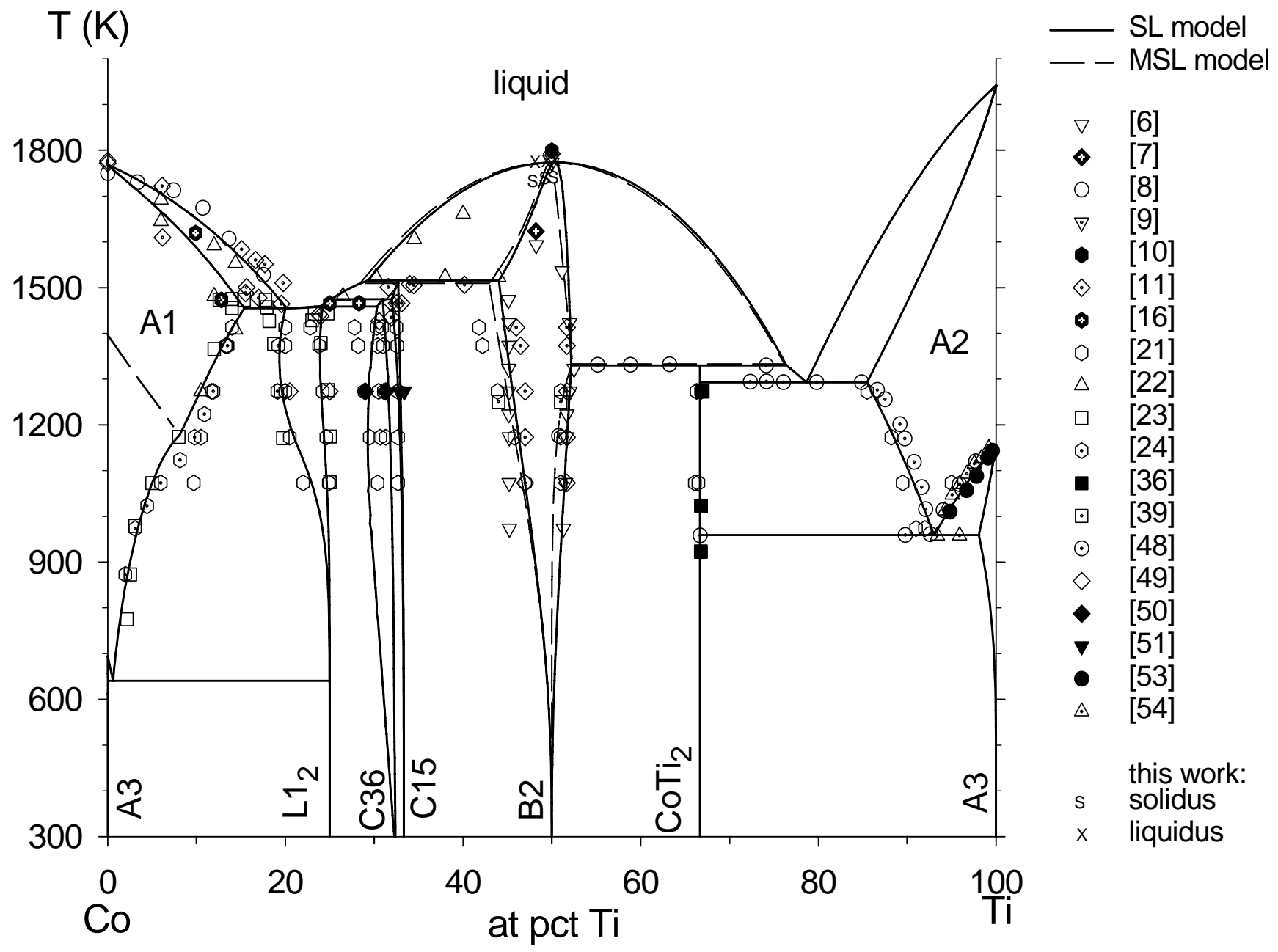

Fig. 10. Assessed diagram as compared to the evaluated experimental data. 


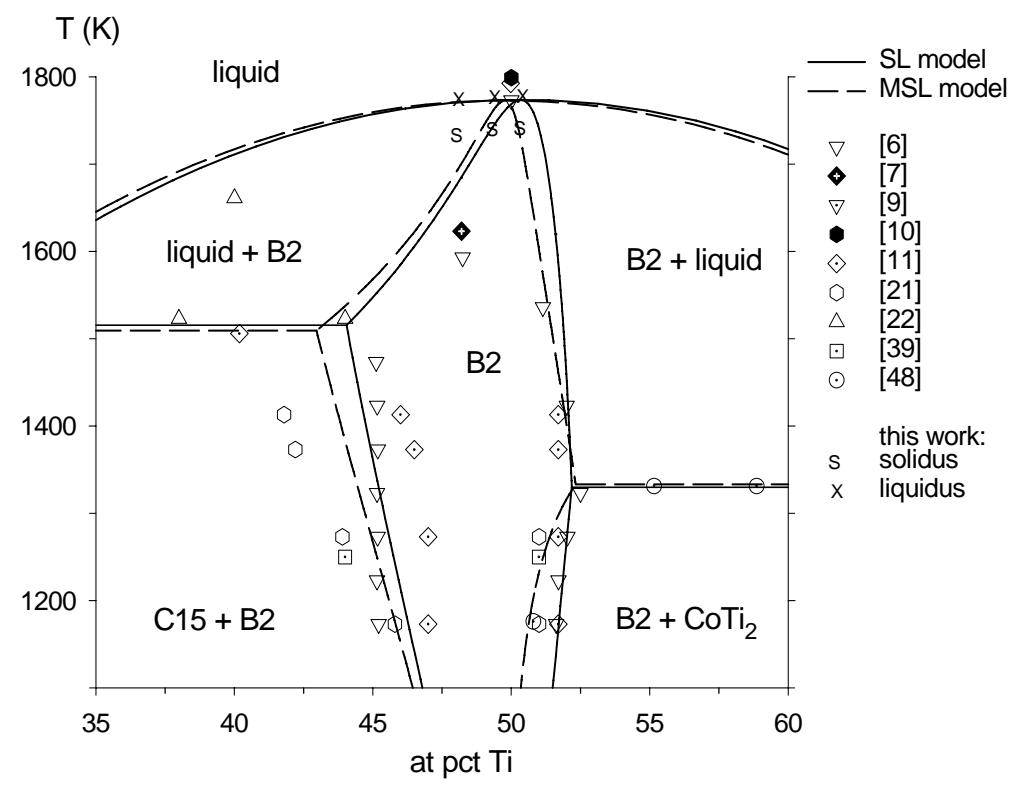

Fig. 11. Assessed phase diagram in the vicinity of the B2 phase. 


\section{Figure Captions:}

Fig. 1. All experimental data (symbols) compared to the Co-Ti phase diagram evaluated by Murray ${ }^{[5]}$ (solid and dashed lines).

Fig 2. DTA curves of the Co-Ti alloys: I (48.1 at pct Ti); II (49.4 at pct Ti), III (50.4 at pct Ti). Horizontal arrows identify heating and cooling curves. Vertical arrows indicate solidus and liquidus thermal arrests; vertical diamond arrow (sample I, cooling curve) identifies peritectic reaction: $\mathrm{B} 2+$ liquid $\rightarrow \mathrm{C} 15$.

Fig 3. SEM image of sample I equilibrated at $1733 \mathrm{~K}$ : partial melting at the grain boundaries is clearly visible (note scratches from polishing on the intact surface)

Fig 4. XRD pattern of sample I after the DTA run: arrows indicate presence of the C15 phase; * - residual alumina reflections (from the crucible material).

Fig 5. Cross-sectional back-scattered SEM microphotographs of:

(a) sample II solidified from $1753 \mathrm{~K}$ : dark matrix is B2 phase (49.5 to 49.8 at pct Ti); lighter areas at the grain boundaries are enriched with cobalt (34 to $42 \% \mathrm{Ti}$ ); bright particles - Laves (C15) phase;

(b) sample III solidified from $1783 \mathrm{~K}$ : light-gray to gray matrix is B2 phase (49.6 to 49.9 at pct Ti); dark particles are Ti-rich A2 solid solutions with 89 to 94 at pct Ti.

Fig. 6. Selected solvus data in the Co-rich corner of the phase diagram as compared to the present assessment (insert shows detailed equilibria involving $\mathrm{L1}_{2}$ and liquid phases).

Fig. 7. Experimental and calculated Curie temperature $\left(T_{c}\right)$ for the A1 phase

Fig. 8. Experimental and calculated enthalpy of formation of intermetallics at $298 \mathrm{~K}$.

Fig. 9. Experimental and calculated $\Delta{ }^{\mathrm{mix}} \mathrm{H}$ in the liquid.

Fig. 10. Assessed diagram as compared to the evaluated experimental data.

Fig. 11. Assessed phase diagram in the vicinity of the B2 phase. 